\title{
LIMITED LIABILITY WITH ONE-MAN COMPANIES AND SUBSIDIARY CORPORATIONS
}

\author{
Bernard F. Cataldo*
}

Limited liability, usually regarded as the most significant feature of corporate enterprise, has received extravagant praise. Among those who have paid verbal homage to the concept of limited liability are two former university presidents who cut a large figure in the intellectual manners of the nation during the last half century. President Eliot of Harvard regarded limited liability as "the corporation's most precious characteristic" and "by far the most effective legal invention . . . made in the nineteenth century."1 President Nicholas Murray Butler of Columbia made the pronouncement in Igrr: "I weigh my words when I say that in my judgment the limited liability corporation is the greatest single discovery of modern times. ... Even steam and electricity are far less important than the limited liability corporation, and they would be reduced to comparative impotence without it."

Our courts have rested-unnecessarily, it is believed ${ }^{3}$-the concept of limited liability on the legal entity theory. This theory, familiar to every elementary student of corporation law and finance, treats the corporation as a legal persona or juristic person constituting an entity in itself separate and distinct from the members. The essence of this theory, stated in stark terms, is that the shareholders own "the corporation" and the latter owns and operates the assets and the business. The questionable $e^{4}$ but judicially accepted reasoning which regards limited liability as a

* A.B. I929, LL.B. I932, LL.M. x936, University of Pennsylvania. Member of Philadelphia bar; Special Attorney, Department of Justice, Washington, D. C., r935-36; Chief Price Attorney, Office of Price Administration, Philadelphia Regional Office, I943-45; Professor of Business Law and Chairman of the Department, Wharton School, University of Pennsylvania. Contributor to legal and other periodicals.

"Quoted in Cook, "Watered Stock"-Commissions-"Blue Sky Laws"-Stock Without Par Value, I9 Mich. L. Rev. 583 D. 4 (xg2I).

${ }^{2}$ Quoted in I William M. Fletcher, Cyclopedia of the Law of Corporations \$2I (1917). See Berl, The Vanishing Distinction Between Creditors and Stockholders, 76 U. of PA. L. REv. 814, 815 (1928). See also Dodd, The Evolution of Limited Liability in American Industry: Massachusetts, $6 \mathrm{r}$ HARV. L. REv. I35I (I948).

${ }^{3}$ It is not intended to pursue here the old and fruitless quarrel engendered by the "nature of corporateness." The legal entity theory has taken deep root in our legal system and continues to flourish, though as far back as 1884 , one writer decried the theory as a vestigial organ requiring excision. HENRY $O$. 'Taylor, Private Corporations iv (1884). See Machen, Corporate Personality, 24 Harv. L. Rev. 347, 352 (rgir); Frederick Hallis, Corporate Personality lxi (1930).

- See preceding note. See also I. Maurice Wormser, Disregard of the Corporate Fiction and Allied Corporation Problems 29 (1927); Adolf A. Berle, Studies in the LAw of Corporate Finance c. I (1928); Alexander H. Frey, Cases and Materials on Corporations and Partnerships 5I (I95I); Koessler, The Person in Imagination or Persona Ficta of the Corporation, 9 LA. L. Rev. 435 (1949).

Ballantine, Separate Entily of Parent and Subsidiary Corporations, I4 CaI. L. REv. I2, 20 (1925), states that the entity theory is the "basic theory of corporation law."

A new concept in the field is set forth by Berle, The Theory of Enterprise Entity, 47 CoL. L. REv. 343 (1947). 
result flowing out of the legal entity theory follows a simple route: The corporation is a separate entity; hence the obligations incurred in the operation of the business are those of the corporation itself, and the shareholders are not personally liable on those obligations.

The extent to which the courts have gone in upholding the doctrine of corporate entity and its companion, limited liability, finds vivid illustration in those cases which concern the closest of close corporations-the one-man company, the family corporation, and the subsidiary corporation.

\section{I}

\section{The One-Man Company and Family Corporation ${ }^{5}$}

The evolution of the one-man company and the family corporation is found in the desire to combine limited liability with the complete dominion of the sole proprietorship. ${ }^{6}$ A sole proprietor, operating a moderate sized business, organizes a corporation to which he surrenders the business and assets. In return he takes all the shares excepting the few necessary to comply with the statutory provisions respecting incorporators and directors. The few shares he does not take are allotted to his relatives or employees, in order to qualify them as incorporators or directors in accordance with the requirements of the corporation statute. Thus, a corporation is created "in legal form," the sole or principal shareholder retains in effect the exclusive control and full dominion he enjoyed as a sole proprietor, and in addition he achieves the desired privilege of limited liability. ${ }^{\top}$

It is most doubtful whether the concept of corporate enterprise was ever intended or designed to embrace this institution. ${ }^{8}$ Nevertheless the one-man company and the family corporation have become familiar modes of business enterprise and, despite occasional questioning by a court $^{9}$ or a writer, ${ }^{10}$ have generally received judicial

'Fuller, The Incorporated Individual: A Study of the One-Man Company, 5I HARv. L. REv. 1373 (1938); Masten, "One Man Companies" and Their Controlling Shareholders, 14 CAN. BAR REv. 663 (1936); Note, One Man Corporations-Scope and Limitations, noo U. of PA. L. REv 853 (1952).

- Occasionally there have been other motives for the formation of one-man companies. Some of these other motives have been: a married man's wish to avoid the incidents of dower with respect to certain realty, a person's desire to avoid the operation of a usury statute which applies to individuals but not to corporations, the desire to facilitate the management and sale of property. See Fuller, stipra note 5 , at 1374 .

Tote, 45 Harv. L. Rev. ro84 (1932).

${ }^{8}$ Rutledge, Significant Trends in Modern Incorporation Statutes, 22 WASH. U. L. Q. 305 (1937), suggests a study to determine the advisability of having three types of corporation statutes: one for the extensive business, another for the small or moderate sized businesss, another for the one-man company. See Israels, The Close Corporation and the Law, 33 CornelI L. Q. 488 (1948).

Note, "One Man Corporations"-Scope and Limitations, 100 U. of PA. L. REv. 853, 868 (1952): "Inasmuch as the one man corporation can be justified on economic and social grounds, and since it has been recognized by the courts for over half a century, it would seem advisable that the legislatures of the several states follow the lead of Michigan and Iowa and permit one man to form a corporation and eliminate the board of directors. This would simplify the entire problem and dissolve the aura of disrespectabilty and uncertainty which still hovers over the one man corporation."

${ }^{-}$See Dollar Cleaners \& Dyers, Inc. v. MacGregor, 163 Md. 105, I61 Atl. 159 (1932).

${ }^{10}$ Note, 45 HARv. L. Fev. 1084, 1089 (I932): "Limited liability-a protection designed to encourage investment in corporations-would seem unnecessary where corporate ownership and control has been concentrated in the hands of one man. An occasional questioning by the courts of the desirability of 
sanction and approval. The usual argument advanced by the courts is: Limited liability is a privilege held out by the corporation law of the state; one who organizes a one-man or family corporation, in compliance with the formalities of that law, for the purpose of attaining limited liability in a commercial venture, is merely taking advantage of a privilege conferred by law. ${ }^{11}$ One might well question both the logic and the historical realities in this judicially tailored reasoning. What is far more important, however, is that this and similar reasoning indicates clearly a judicial policy to sponsor the one-man company and the family corporation. ${ }^{\mathbf{1 2}}$

\section{A. Contractual Obligations}

The fact that all or almost all the shares of a corporation are owned by one individual is not sufficient ground for disregarding corporate personality. ${ }^{13}$ This view seems now too settled for dispute. ${ }^{14}$ Accordingly the distinction between the corporate property and the individual property of the sole shareholder is carefully preserved for legal purposes. ${ }^{15}$ The same is true of the distinction between corporate obligations and the personal obligations of the sole shareholder. Corporate creditors

the one man corporation is indicative of this point of view." See I. Maurice Wormser, Frankenstein INCORPORATED 95 ff. (193I).

${ }^{11}$ Elenkrieg v. Siebrecht, 238 N. Y. 254, I44 N. E. 5 I9 (1924); Salomon v. Saloman \& Co., Ltd. [1897] A. C. 22. See Inland Revenue Commissioners v. Sansom, [r92r] 2 K. B. 492, 500, I25 L. T. R. 37.

${ }^{12}$ In Inland Revenue Commissioners v. Sansom, [I92I] 2 K. B. 492, 514, I25 L. T. R. 37, Younger, L. J., said: "Now, spcaking for myself, I do in the light of these considerations, deprecate in connection with what are called one-man companies, the too indiscriminate use of such words as simulacrum, sham, or cloak-the terms found in this case or indeed any other term of polite invective. Not only do these companies exist under the sanction, even with the encouragement of the Legislature, but I have no reason whatever to doubt that the great majority of them are as bona fide and genuine as in a business sense they are convenient and suitable media for the provision and application of capital to industry.

No doubt there are amongst such companies, as amongst any other kind of association, black sheep; but in my judgment such terms of reproach as I have alluded to should be strictly reserved for those of them and of their directors who are shown to deserve condemnation, and I am quite satisfied that the indiscriminate use of such terms has, not infrequently, led to results which are unfortunate and unjust, and in my judgment this is no case for their use."

${ }^{13}$ Macan v. Scandinavia Belting Co., $264 \mathrm{~Pa} .384,39 \mathrm{r}$, ro7 Atl. 750, 752 (r919): "A corporation has a separate entity or existence, irrespective of the persons who own its stock, and this rule is not altered by the fact that the greater portion or even the entire issue of stock happens to be held by one person." See Star Brewing Co. v. Flynn, 237 Mass. 213, I29 N. E. 438 (r92I); Eichelberger v. Arlington Building, Inc., 280 Fed. 997, 999 (D. C. Cir. 1922).

14 In re John Koke Co., 38 F. 2d 232, 233 (9th Cir. 1930): "The rule is quite elementary that a corporation is an entity separate and distinct from its stockholders, with separate and distinct rights and liabilities; and this is true even though a single individual may own all, or nearly all, of the capital stock."

Commerce Trust Co. v. Woodbury, 77 F. 2d 478, 487 (8th Cir. I935): "Few questions of law are better settled than that a corporation is ordinarily a wholly separate entity from its stockholders, whether they be one or more." See Corley v. Cozart, II5 F. 2d II9, I21 (5th Cir. I940).

${ }^{15}$ The leading American decisions are Button v. Hoffman, 6x Wis. 20, 20 N. W. 667 ( 1884 ), and Parker v. Bethel Hotel Co., 96 Tenn. 252, 34 S. W. 209 ( 1896 ). In the Button case the sole shareholder was unsuccessful in an action of replevin brought in his individual name to recover corporate assets from one wrongfully in possession of them. See also Moroney v. Moroney, $286 \mathrm{~S}$. W. I67 (Tex. Comm. App. 1926). In the Parker case the court held inoperative the sole shareholder's attempt to alienate corporate property in his individual name. Accord: Corley v. Cozart, xI5 F. 2d IIg (5th Cir. 1940). Cf. Earp v. Schmitz, 334 Ill. App. 382, 79 N. E. $2 d 637$ (1948). See Walter H. Anderson, Limitations of CoRporate Entity 97 (I93I). 
cannot obtain satisfaction from the sole shareholder and his individual property; ${ }^{10}$ creditors of the sole shareholder cannot obtain satisfaction from the corporation and corporate assets. ${ }^{17}$ The same general principle governs in the matter of set-off. ${ }^{18}$ For example, in a case where an insolvent bank held the deposit of a corporation and the individual note of that corporation's sole shareholder, the latter was not allowed to set off the amount of the deposit against his liability on the note. ${ }^{10}$

This distinction between corporate and individual obligations and creditors, and the ensuing limited liability of the sole shareholder, may be supported on extra-legal and purely pragmatic grounds. The obligee of a contractual obligation has an opportunity of knowing and choosing his obligor. He should know with whom he is dealing and should be bound by his choice. If insolvency overtakes the sole shareholder, or the corporation, or both, it is necessary to weigh the respective positions of those who dealt with the business on a corporate basis and those who dealt with the sole shareholder as an individual. The equities of the former are no greater than those of the latter. The former will be limited to the corporate assets; the latter, to the individual assets. By this marshalling, the equal equities of both groups are preserved, in the usual and ordinary case.

As a simple example, suppose a draft names a corporate drawee. The draft is accepted by the drawee in the corporate name and is later discounted by a bank. It turns out that the acceptor is a one-man company. The bank may not hold that company's sole shareholder liable on the instrument, even though the company becomes insolvent and is unable to pay. ${ }^{20}$ The acceptance appearing on the instrument was in a corporate name and the bank had an opportunity to determine the real identity of the acceptor before it discounted the draft. The bank receives all it bargained for when it is given a legal remedy on the instrument against the corporation. If the bank and other corporate creditors were permitted to hold the sole shareholder liable, the latter's individual assets would be depleted at the possible expense of his personal creditors who dealt with him as an individual and should have priority in his personal assets.

It is a fair guess that courts are motivated by these considerations, ${ }^{21}$ although they

${ }^{10}$ Louisville Banking Co. v. Eisenman, 94 Ky. 83, 2 I S. W. 531 (I893). See Robert S. Stevens, Handbook on the Law of Private Corporations 75 (2d ed. 1949): "When one extends credit to a corporation, he may not, upon the insolvency of the corporation, claim satisfaction out of the individual property of the sole shareholder. ..." See EDward H. WARREN, SELEct Cases and OTHER Authorities on the Law of Private Corporations 89 note (1916, Reprint of 1930). Cf. Re O'Brien, $40 \mathrm{~F} .2 \mathrm{~d} 554$ (D. Minn. 1930).

${ }^{17}$ In re John Koke Co., 38 F. $2 d 232$ (9th Cir. 1930); Geary v. Cain, 79 Utah 268, 9 P. $2 d 396$ (1932). See Star Brewing Co. v. Flynn, 237 Mass. 213, r29 N. E. 438 (1921); Tinnin v. Wilkirson, 58 S. W. 2d 69 (Tex. Comm. App. I933).

${ }^{18}$ Looney v. Thorpe Bros., 277 Fed. 367 (8th Cir. 1921); Gallagher v. Germania Brewing Co., 53 Minn. 214, 54 N. W. III5 (1893). But see U. S. Gypsum Co. v. Mackey Wall Plaster Co., 6o Mont. 132, I99 Pac. 249 (r921). Cf. Gay v. Hudson River Electric Power Co., 187 Fed. 12 (2d Cir. 1911).

${ }^{10}$ State ex rel. Sorensen v. Weston Bank, 125 Neb. 612, 251 N. W. I64 (I933). Accord: Dennis v. Smith, 49 S. W. 2 d 909 ('Tex. Civ. App. 1932).

${ }^{21}$ Louisville Banking Co. v. Eisenman, $94 \mathrm{Ky} .83$, 21 S. W. 531 (1893).

${ }^{21}$ Sce the excerpt from Lord Herschell's opinion in Salomon v. Saloman \& Co., Ltd. [1897] A. C. 22, quoted in note 31, infra. A recent case which seems to push this attitude too far, in view of the 
generally prefer to place their decisions on the simple base of the legal entity theory. A case which is unusual in this regard, because the "election" factor appears in bold relief and the court mentions the conflicting equities of rival groups of creditors, is In re John Koke Co., ${ }^{22}$ decided in 1930 by the United States Court of Appeals for the Ninth Circuit. Here money was borrowed personally by the sole shareholder of a corporation for the declared purpose of paying off corporate debts. Upon the subsequent bankruptcy of both the shareholder and the corporation, the lender sought to share as a corporate creditor with a claim against the corporate assets. The court denied his claim and said that since he knew the purpose of the loan he was "bound by the election thus made, in view of the possible intervening rights of other creditors."

\section{B. Tort Liability}

The foregoing reasoning would not be applicable to tort liability. Needless to say, in the ordinary case the victim of a tort does not rely on, deal with, or choose his tortfeasor. It is conceivable, therefore, that courts might distinguish in this connection between contractual obligations and tort liability. They might refuse to sponsor limited liability for the sole shareholder in the one-man company with respect to "strangers" injured by a tort committed in the execution of the corporate business, although they have sustained limited liability for such a shareholder with respect to contractual obligations. The courts have, however, neither drawn nor honored this distinction. The sole or principal shareholder has been held not to be personally liable to a party injured by the negligent act of a corporate employee, ${ }^{23}$ or by the negligent maintenance of the corporate property. ${ }^{24}$ In the leading case to this effect, decided by one of our most respected tribunals, the plaintiff was injured by reason of the faulty construction and negligent maintenance of a building, which was owned and operated by a realty company and had been leased by it to various tenants. The New York Court of Appeals held that the plaintiff, an employee of one of the tenants, had no right of action against the principal shareholder of the realty company. The court exclaimed: ${ }^{25}$

The fact that it is a family corporation, so to speak, is nothing suspicious or illegal. Innumerable are the corporations wherein all the stock is owned by a few members of one family. The fact that one man may own all but a few shares of the stock, and be

particular circumstances there disclosed, is Westervelt's Sons v. Regency, Inc., 63 A. 2d 818 (N. J. Super. Ch. 1948), aff'd, 3 N. J. Super. $1_{73}, 65$ A. $2 d 776$ (1949). Here the court said (p. 820): "The plaintiff contracted with Regency, Inc. Presumably plaintiff intended to look to the assets of Regency, Inc. for the payment of its claim. Had plaintiff intended to charge the van Doorns personally it would have insisted upon having them join in the contract. All the plaintiff can ask is that the assets of Regency, Inc. shall be made available for the payment of its claim. The fact that there are other claims and that bankruptcy has intervened does not alter the situation."

${ }^{28} 38$ F. 2d 232, 233 (9th Cir. I930).

${ }^{23}$ Sayers v. Navillus Oil Co., 4I S. W. 2 d 506 (Tex. Civ. App. I93I); Hayhurst v. Boyd, 5o Idaho 752, 300 Pac. 895 (I93I). Cf. Cooper v. Industrial Commission, 74 Ariz. 351, 249 P. 2d I42 (I952); Price v. Old Label Liquor Co., 23 N. J. Super. I65, 92 A. 2d 806 (1952).

24 Elenkrieg v. Siebrecht, 238 N. Y. 254,144 N. E. 519 (1924).

${ }^{25}$ Elenkrieg v. Siebrecht, 238 N. Y. at 260,262, r 44 N. E. at 521 . 
in fact the dominant and controlling factor or the only active manager of the corporation, is no evidence in and of itself that the corporation does not exist as a person in the eyes of the law, actually owning, operating, and controlling property. ... Many a man incorporates his business or his property and is the dominant and controlling feature of the corporation. He may do so for the very purpose of escaping personal liability, and he may do so as a cover if in fact the corporation really exists-is doing business as permitted by the laws of this state or the state of its incorporation; in other words, is a person recognized by the law.

In the cases found dealing with this problem the tort concerned was negligence. There is a question whether the same rule should govern respecting tortious misconduct which is intentional or deliberate, such as the tort of assault or false imprisonment committed in the execution of the corporate business by an employee or by the sole shareholder himself. Conceivably the sole shareholder might be denied the privilege of limited liability when he has himself committed a tort of this character within the scope of the corporate business. ${ }^{26}$ It is likely, though, that the courts will, without distinction, apply the broad standard of limited liability to both classes of torts, just as they have, without distinction, upheld limited liability for both contractual obligations and tort liability for negligence. ${ }^{27}$

\section{The Sole Shareholder as a Corporate Creditor}

It is natural for the courts, having proceeded to this point, to hold that the sole shareholder may lend money to the business and share as a corporate creditor upon the subsequent insolvency of the venture. ${ }^{28}$ Indeed, the sole or principal shareholder may become a secured corporate creditor and thus acquire priority over the unsecured corporate creditors. This position was sustained by the eminent authority of the English House of Lords a half century ago in Salomon v. Salomon \& Co., $L t d .{ }^{29}$ a decision which haunts every discussion of corporate entity and limited liability. The essential facts of this celebrated case were that Salomon, a prosperous sole proprietor in the boot and shoe business, desirous of achieving limited liability, formed a corporation with an authorized share capital of 40,000 pounds (40,000 shares

\footnotetext{
${ }^{20} \mathrm{~A}$ decision which seems to sustain this position, without any explanation or discussion of the matter, is found in the case of Jackson v. Kirschman, I75 So. 105 (La. App. 1937).

${ }^{27}$ In Geary v. Cain, 79 Utah 268, 9 P. $2 d 396$ (1932), the plaintiff was assaulted by $C$ and obtained judgment against $C$. He sought to reach, in satisfaction of this judgment, the assets of a family corporation of which $C$ was actually the sole shareholder, but did not succeed. At first glance it scems as if a new and startling type of spendthrift trust is being sanctioned whereby a hothead may transfer his assets to a corporation and thus place them beyond the reach of those whom he intentionally harms in the future. The case is hardly so ominous and its significance seems to be primarily procedural. C's shares are his personal property, and the plaintiff, like any other creditor of $C$, may reach those shares in satisfaction of the judgment entered against $C$. In this way the plaintiff will reach $C$ 's net worth in the corporate venture, without injury to the corporate creditors. The equities of the corporate creditors, who have priority in the corporate assets, and of the plaintiff, who has a claim against the sole sharcholder as an individual, are kept in balance.

${ }^{28}$ Wheeler v. Smith, 30 F. 2d 59, 61 (9th Cir. 1929): "While the claim of al sole stockholder against a bankrupt corporation should be scrutinized with care, it is not the law that such a claim should be rejected merely because the claimant is such sole stockholder." See Peckett v. Wood, 234 Fed. 833 (3d Cir. 1916); Gardner v. Rutherford, 57 Cal. App. 2d 874, 136 P. 2d 48 (1943). Cf. Pott v. Schmucker, 84 Md. 535,36 Atl. 592 (1897).

20 [1897] A. C. 22.
} 
with a par value of I pound each). He surrendered his solvent business at the overvalued figure of 39,000 pounds to the corporation. In return the corporation assumed the obligation of paying off the debts of the old business, amounting to 1000 pounds, and Salomon received 20,00r shares and roo debentures. The latter had a par value of roo pounds each and represented a lien on the corporate assets. His wife and five children, who served as the incorporators along with him, were allotted one share each, and no other shares were ever issued. Salomon and two sons constituted the board of directors, and Salomon was appointed chairman of the board and managing director. On the security of his debentures Salomon borrowed from Broderip 5000 pounds, which were paid into the corporate treasury as a loan from Salomon. As part of the transaction, the debentures held by Salomon were cancelled, new debentures in the same amount were issued to Broderip, with the understanding that Salomon was the "beneficial owner" of the new debentures, subject only to Broderip's prior security interest therein to the extent of the loan in question. Business adversity, in the form of strikes in the trade and the government's failure to give the number of orders anticipated, caused the corporation to become insolvent. In liquidation proceedings instituted some fourteen months after incorporation, it was held that: first, Broderip was entitled to full payment of his claim; second, the balance of the assets, about Iooo pounds, should go to Salomon "as beneficial owner of the debentures"; third, the unsecured creditors, with claims amounting to about 8000 pounds, would receive nothing.

Salomon, the bootmaker, and Salomon \& Co., Ltd., were distinct and separate persons, ${ }^{30}$ the Lords argued, and the fact that he incorporated for the purpose of achieving limited liability was of no moment, since limited liability is a legitimate and permissible object of incorporation, conferred by the corporation law of the realm. ${ }^{31}$

${ }^{30}$ Lord Herschell said (pp. 42-43): "Under these circumstances, I am at a loss to understand what is meant by saying that A. Salomon \& Co., Ltd., is but an 'alias' for A. Salomon. It is not another name for the same person; the company is ex hypothesi a distinct legal persona. As little am I able to adopt the view that the company was the agent of Salomon to carry on his business for him. In a popular sense, a company may in every case be said to carry on business for and on behalf of its shareholders; but this certainly does not in point of law constitute the relation of principal and agent between them or render the shareholders liable to indemnify the company against the debts which it incurs."

31 Lord Herschell declared (pp. 44-45, 46): "It is said that the respondent company is a "one man' company, and that in this respect it differs from such companies as those to which $I$ have alluded. But it has often happened that a business transferred to a joint stock company has been the property of three or four persons only, and that the other subscribers of the memorandum have been clerks or other persons who possessed little or no interest in the concern. I am unable to see how it can be lawful for three or four or six persons to form a company for the purpose of employing their capital in trading, with the benefit of limited liability, and not for one person to do so, provided, in each case, the requirements of the statute have been complied with and the company has been validly constituted. How does it concern the creditor whether the capital of the company is owned by seven persons in equal shares, with the right to an equal share of the profits, or whether it is almost entirely owned by one person, who practically takes the whole of the profits? The creditor has notice that he is dealing with a company the liability of the members of which is limited, and the register of shareholders informs him how the shares are held, and that they are substantially in the hands of one person, if this be the fact. . . . But we have to interpret the law, not to make it; and it must be remembered that no one need trust a limited liability company unless he so please, and that before he does so he can ascertain, if he so please, what is the capital of the company, and how it is held." 
Some thirty years later the Maryland court, faced with the same issue, reached a different conclusion and drily remarked: "This court does not think the law contemplates that one may incorporate an established business of his own, continue to own and control it as before, and at the same time, for his personal benefit, put beyond the reach of prospective creditors all the assets of the corporation." ${ }^{32}$

\section{Disregard of Corporate Personality}

The concept of corporate personality will be sustained only so long as it is invoked and employed for legitimate purposes. Courts will not sanction a perversion of the concept to improper uses and dishonest ends. A perversion is clearly perceived when the notion of corporateness is used as a device to perpetuate fraud, to evade the law, or to escape obligations. ${ }^{33}$ In cases of this gender the courts do

${ }^{32}$ Dollar Cleaners \& Dyers, Inc. v. MacGregor, I63 Md. 105, 109, 16r Atl. 159, I6x (1932).

Professor Ripley's sentiments were the same. Speaking of the Salomon case, he said: "The House of Lords, on the other hand, concluded the matter by holding that, inasmuch as all legal formalities had been duly observed, there was no fraud. Fraud or no fraud, to the lay mind the whole flimsy pretext more than borders on the ridiculous. It rather controverts the famous characterization of Disracli, that 'the legal mind chiefly displayed itself in illustrating the obvious, explaining the evident, and expatiating on the commonplace." "WilliaM Z. Ripley, MAIN Street AND WALL StreEt 64-65 (1927).

Complete approval of the Salomon case was expressed in Inland Revenue Commissioners v. Sansom, [I92I] 2 K. B. 492 , r25 L. T. R. 37.

One writer, speaking in 1936 , said that "the principle of the Salomon Case stands unimpaired." Masten, One Man Companies and Their Controlling Shareholders, $1_{4}$ CAN. BAR. REv. 663, 671 (1936).

${ }^{33}$ United States v. Milwaukee Refrigerator Transit Co., I42 Fed. 247, 255 (C. C. E. D. Wis. I905): "If any general rule can be laid down, in the present state of authority, it is that a corporation will be looked upon as a legal entity as a general rule, and until sufficient reason to the contrary appears; but, when the notion of legal entity is used to defeat public convenience, justify wrong, protect fraud, or defend crime, the law will regard the corporation as an association of persons." Sce Eichelberger v. Arlington Building, Inc., 280 Fed. 997, 999 (D. C. Cir. I922); Kutz Canon Oil \& Gas. Co. v. Harr, 56 N. M. 358, 244 P. 2d 522, 527 (1952).

Pacific Can Co. v. Hewes, 95 F. 2d 42, 45 (9th Cir. 1938): "A familiar principle of law has been that a corporation is an entity, distinct in itself. It is true that when resourcefulness of man caused a corporation to be used as a scapegoat for another, courts checked the evil."

Ruberoid Co. v. North Texas Concrete Co., 193 F. 2d 121, 122 (5th Cir. 1951): "The doctrine of separate entity fills a useful purpose in business life, and the courts are hesitant to disregard it unless the facts presented demonstrate some misuse of the corporate privilege or the need of limiting it in order to do justice."

The problem is pursued at length in the article by Horowitz, Disregarding the Entity of Private Corporations, 14 WASH. L. REv. 285 (1939), 15 WASH. L. REv. I (1940). See also Note, Piercing the Corporate Veil, 4 U. OF FLA. L. REv. 352 (195I). A special aspect of this problem, dealing with the corporation as a "person" under the New York usury law, is found in Note, 38 CorNelz L. Q. 93 (r952).

Some of the schemes are so transparent as to leave one incredulous. It is a fair guess, though, that for each scheme which is brought before the courts and judicially unraveled at great expense to the litigant, there are many which do not reach the courts and are suecessful.

In Great Oak Bldg. Ass'n v. Rosenheim, 34 I Pa. I32, I9 A. 2d 95 (194I), the plaintiff held a mortgage on property owned by the defendant, who transferred it to a one-man company crcated for the purpose with an authorized share capital of $\$ 500$. Of the roo shares authorized he took 98 , and his wife and daughter each took one. The corporation assumed the obligation to pay off the mortgage and to pay the defendant $\$ 500$, in return for the transfer of property, and no cash or other assets were paid or exchanged. The defendant continued to collect rents as he had in the past and put them in his personal bank account, except for the amounts necessary to pay the expense of maintaining the property. There were no corporate books and no corporate bank account. The whole purpose of the arrangement was, the defendant conceded, to relieve him of personal liability on the mortgage debt. After the foreclosure of the mortgage by the plaintiff, the latter was obliged to satisfy unpaid taxes on the property. The defendant was held personally liable to reimburse the plaintiff for the amount of the 
not permit parties to play hide-and-seek by assuming the dual role of human being, on the one hand, and corporation, on the other. Acts done in corporate form will be considered the individual acts of the members, ${ }^{34}$ and acts done by the members will be considered corporate acts. ${ }^{35}$

Though it is undeniable that the notion of corporate personality will be disregarded when invoked to "defeat public convenience, justify wrong, protect fraud, or defend crime," it would be erroneous to assume that this general rule states the limits of judicial action in the matter. There is a marked tendency to disregard corporate personality in those cases where adherence to the concept of corporateness will result in inequity or will prevent a full settlement of the dispute between the

taxes in question. The court said (341 Pa. at 137, i9 A. $2 \mathrm{~d}$ at 97): "With this principle in mind, the paper mask of the charter, because it is nothing more, will not be permitted to hide the features of the individual behind it."

In Higgins v. Smith, 308 U. S. 473, 475 (I940), a one-man company was formed for the purpose of buying securities from and selling securities to the sole shareholder. The shareholder was not permitted to deduct a loss arising from the sale of securities from him to the corporation. The jury, pursuant to instructions from the court, found that there was not a real transfer "out of Mr. Smith and into something that existed separate and apart from him," but simply "a transfer by Mr. Smith's left hand, being his individual hand, into his right hand, being his corporate hand, so that in truth and fact there was no transfer at all." See Anderson v. Abbott, 321 U. S. 349 (I944).

${ }^{34}$ Claude Neon Lights, Inc. v. Federal Neon Tube Corporation, 52 F. $2 \mathrm{~d}$ 169 (S. D. N. Y. 193x); Mosher v. Salt River Valley W. U. Ass'n, 39 Ariz. 567, 8 P. $2 d$ 1077 (x932); Veterans Service Club v. Swceney, 252 S. W. 2d 25 (Ky. App. 1952); Biscayne Realty \& Ins. Co. v. Ostend Realty Co., 109 Fla. I, I48 So. 560 (1933).

In the case last cited, Busch and his wife were engaged in the real estate business. He owned all but a very few shares in a corporation which had no assets, did no business, and was used merely as a medium for taking title to lands purchased by Busch. His practice was to buy land, take title in the corporate name, and then have the title transferred from the corporate name to himself and/or his wife. On one occasion he purchased realty, took title in the corporate name, paid part of the price, and for the balance gave the seller promissory notes executed in the corporate name. Title to the property was then transferred from the corporate name to Busch. The promissory notes were not paid and the seller sued the corporation and obtained judgment against it. Unable to collect the judgment from the corporation, he asked the court to declare Busch personally liable on the notes and to subject Busch's individual assets to payment of the judgment. The court gave the relief sought and said that the corporation was a mere alter ego of Busch, who was in effect conducting an individual business under a trade name. The court declared (Iog Fla. at I8, I48 So. at 564): "If the stockholders of a corporation enter into a transaction in their individual and private interests, and utilize the name of the corporation merely as a convenience for the completion of the transaction, where the legal entity as such has no interest in the matter, but the name is used to mislead creditors or perpetuate a fraud upon them, the legal entity in the name of which the transaction was carried will be ignored and the parties held to individual liability." See also Bressman Inc. v. Mosson, 127 Misc. 282, 215 N. Y. Supp. 766 (Ist Dep't r926); Shea v. Leonis, I4 Cal. 2d 666, 96 P. $2 d$ 332 (r939); Natelson v. A. B. L. Holding Co., Inc., 260 N. Y. 233 , I 83 N. E. 373 (1932), where the court said (260 N. Y. at 238,183 N. E. at 374) that "liability, divorced from the means of meeting it, was the sole portion of the corporation. ... This, we think, pushes the theory of dual personality too far."

${ }^{3 x}$ Norma Mining Co. v. Mackay, 24I Fed. 640 (9th Cir. I9I7); Wenban Estate, Inc. v. Hewlett, I93 Cal. 675, 227 Pac. 723 (1924).

The two classical instances are People v. North River Sugar Refining Co., I2I N. Y. 582, 24 N. E. 834 (1890), and State v. Standard Oil Co., 49 Ohio 137, 30 N. E. 279 (1892).

A striking example is the case of the sole or principal shareholder who sets fire to corporate property. Corporate personality is disregarded in order to prevent the shareholder from profiting by his own wrong, and his incendiarism is considered a good defense to a suit brought by the corporation to recover on its fire policy covering the property. Neily Co. v. London \& Lancashire Fire Insurance Co., $I_{4} 8$ Fed. 683 (3d Cir. Ig06). Accord: D. I. Felsenthal Co. v. Northern Assurance Co., 284 Ill. 343 , I 20 N. E. 268 (19x8). Cf. Firemen's Mutual Insurance Co. v. Aponaug Mfg. Co., I49 F. 2d 359 (5th Cir. I945). 
real parties in interest in a given situation. ${ }^{36}$ Under the aegis of this fluid principle a court may move freely in deciding a case on the merits. ${ }^{37}$

These sentiments have special significance with respect to one-man companies and family corporations. Here the sole or principal shareholder, like Janus, represents and constitutes an incorporated venture, on one side, and an individual, on the other side. His complete dominion and superior knowledge carry opportunities for manipulation and maneuvering. ${ }^{38}$ Accordingly his privilege of limited liability is conditioned on compliance with two requirements. ${ }^{39}$ First, he must conduct the business on a corporate footing and thereby maintain and preserve the separate identity of the venture. ${ }^{40}$ Second, he must establish the corporate venture

${ }^{36}$ Thornburgh Construction Co. v. College Heights Development, 244 P. 2d 735 (Cal. App. 1952); D. N. \& E. Walter \& Co. v. Zuckerman, 2I4 Cal. 4I8, 6 P. 2d 25I (r93I); Note, 36 YAle L. J. 254. See Wenban Estate, Inc. v. Hewlett, 193 Cal. 675, 696 f., 227 Pac. 723 (1924); Note, ro MinN. L. Rev. 598, 607 (1926). Cf. Progress Tailoring Co. v. Federal Trade Commission, I53 F. 2d 103 (7th Cir. I946).

Metropolitan Holding Co. v. Snyder, 79 F. 2d 263, 266 (8th Cir. 1935): "There has been a growing tendency upon the part of the courts to disregard corporate entity and to treat the stockholders thercof as an association of individuals when the interests of justice are to be served."

${ }^{37}$ For example, see State Trust \& Savings Bank v. Hermosa Land \& Cattle Co., 30 N. M. 566, 240 Pac. 469 (1925); U. S. Gypsum Co. v. Mackay Wall Plaster Co., 6o Mont. 32, 199 Pac. 249 (I921). Indeed, the court may feel moved to disregard corporate personality in order to protect the corporate shareholders themselves against inequity. Marchman v. McCoy Hotel Operating Co., 21 S. W. $2 \mathrm{~d} 552$ (Tex. Civ. App. 1929), 43 HARv. L. Rev. 83I (1930). See U. S. Gypsum Co. v. Mackay Wall Plaster Co., supra note 37, just cited above. Cf. Crystal Pier Amusement Co. v. Cannan, 219 Cal. 184, 25 P. 2d 839 (I933); Application of Field, 190 F. 2d 268 (Ct. of Cus. and Pat. App. 195I).

The simple truth of the matter is that whether the court will sustain or disregard corporate personality depends upon the policy which the court sponsors in the particular case. Nowhere is this better illustrated than in the cases involving government owned corporations. In these cases corporate personality is sometimes sustained and sometimes disregarded, depending upon the end result considered judicially desirable in the given case. For example, contrast: Sloan Shipyards Corporations v. Emergency Flect Corporation, 258 U. S. 459 (192I); Emergency Fleet Corporation v. Wood, 258 U. S. 549 (I921); United States v. Walters, 263 U. S. 15 (1923); Clallam County v. United States, 263 U. S. 341 (1923); Southern Pacific Co. v. Defense Supplies Corp., 64 F. Supp. 605 (N. D. Cal. 1946), noted in 20 So. Cal. L. Rev. 293 (1947).

Another striking example, concerning one-man companies, is found in two cases decided by the same court in the same year. These are: Erkenbracher v. Grant, r87 Cal. 7, 200 Pac. 64I (1921), and Minifie v. Rowley, I87 Cal. 48I, 202 Pac. 673 (I92I). In both cases the court was obliged to "avoid" the statute of limitations in order to reach a just result. In the first case, it achieved this result by holding that the one-man company concerned was an entity disinct from the sole shareholder. In the second case, it achieved this result by holding that corporate personality should be disregarded and by treating the sole shareholder and the corporation as one party. Accord: Brooklyn Trust Co. v. Povdin, 14 N. J. Super. 470,82 A. 2 d 485 (I95I).

These and similar miscellaneous cases concerning one-man companies are discussed in Note, One Man Corporations-Scope and Limitations, Ioo U. of PA. L. Rev. 853, 865, 866 (1952). Of these cases the writer says: "It is apparent that each case is being decided on its particular facts. The only standard is a just and equitable result. It is impossible to formulate a more definite test."

38 "In all the experience of the law, there has never been a more prolific breder of fraud than the one-man corporation. It is a favorite device for the escape of personal liability." The trial court, as quoted by Mr. Justice Douglas in Pepper v. Litton, 308 U. S. 295, 313, note (1939).

${ }^{39}$ Note, 45 Harv. L. Rev. 1084, I089 (1932): "Opposed to the utility of the corporate device, however, is its peculiar susceptibility to fraudulent use when made available to an individual. The peculiar opportunity for manipulation of assets and the superior knowledge of the sole sharcholder might make it desirable to require that when he claims limited liability, he must show affirmativcly that the corporation was adequately financed and that its financial identity was kept unimpaired."

${ }_{10}^{10}$ In re Looschen Piano Case Co., 26r Fed. 93 (D. N. J. 19r9), a sole proprietor, engaged in the business of manufacturing piano cases, formed two one-man companies. To the first he transferred the 
on an adequate financial basis. ${ }^{41}$

For instance, suppose the business is carried on as if it were the individual business of the sole shareholder, who makes contracts for the business in his own name, keeps no individual bank account, and, without separate accounting, places individual funds and income in the business and draws money from the business for personal needs at his pleasure. Upon the subsequent insolvency of the business he will not be permitted to share as a corporate creditor for sums he advanced to the business as loans. Since he failed to draw a line between his individual and the corporate affairs, the court refuses to draw the line for him and lets him stand where he placed himself. ${ }^{42}$ Likewise, under such circumstances the sole shareholder will be personally liable for obligations incurred in the execution of the business. ${ }^{43}$

The same results follow when the corporation is inadequately capitalized. ${ }^{44}$

realty, to the second he transferred the good will and remaining assets, of the business. No corporate formalities were observed, no separate records were maintained for the two companies, the affairs of both companies were completely "intermingled," and the entire venture was operated, as heretofore, as a sole proprictorship. Upon the bankruptcy of the second company, the trustee was held entitled to the assets of the first company, as part of the bankrupt estate. The court curtly observed (p. 97): "The law will regard two corporations as separate and distinct entities, when they are so regarded and so treated in their operation by their directors or management."

${ }^{41}$ Pepper v. Litton, 308 U. S. 295, 308-310 (I939): "Thus, salary claims of officers, directors, and stockholders in the bankruptcy of 'one-man' or family corporations have been disallowed or subordinated where the courts have been satisfied that allowance of the claims would not be fair or equitable to other creditors. And that result may be reached even though the salary claim has been reduced to judgment. . . . It is also reached where on the facts the bankrupt has been used merely as a corporate pocket of the dominant stockholder, who, with disregard of the substance or form of corporate management, has treated its affairs as his own. And so-called loans or advances by the dominant or controlling stockholder will be subordinated to claims of other creditors and thus treated in effect as capital contributions by the stockholder not only in the foregoing types of situations but also where the paid-in capital is purely nominal, the capital necessary for the scope and magnitude of the operations of the company being furnished by the stockholder as a loan." See Re Merrick Dairy Co., 249 Wis. 295, 24 N. W. 2 d 679 (1946) (salary claims of three dominant shareholder-directors subordinated to claims of general corporate creditors).

${ }^{2}$ Gordon v. Baton Rouge Stores Co., Inc., 168 La. 248, 121 So. 759 (1929). Accord: Re Burntside Lodge, Inc., 7 F. Supp. 785 (D. Minn. 1934); Edward Finch Co. v. Robie, 12 F. 2d 360, 362 (8th Cir. I926): "The corporation and the bankrupt were one and the same. Their affairs were so intermingled and commingled that no individuality or corporate entity is discernible." See HeNRY W. BaLleNTINE, Private Corporations 294 (2d ed. 1946). Cf. Louisville \& Nashville R. R. v. Nield, 186 Ky. 17, 23, $216 \mathrm{~S}$. W. 62, 65 (1919), in which the defendant, according to the court, performed the staggering feat of "swallowing the corporation whole" and thereby became liable for its debts. See Pepper v. Litton, 308 U. S. 295 (1939).

${ }^{13}$ Wittman v. Whittingham, 85 Cal. App. 140, 259 Pac. 63 (1927); Tynes v. Shore, I85 S. E. 845 (W. Va. I936); Western Securities Co. v. Spiro, 62 Utah 623, 211 Pac. 856 (I923). Cf. Lobby Display Frame Corp. v. Steinberg, II4 N. Y. S. $2 d$ d 917 , II5 N. Y. S. $2 d 859$, II7 N. Y. S. $2 d$ d $33^{\circ}$ (1952).

Fuller, The Incorporated Individual: A Study of the One-Man Company, 51 Harv. L. Rev. 1373, ${ }_{1381}$ (1938), argues that the sole shareholder should not be liable merely because he failed "to observe a nice distinction between his dual capacities." The wisdom of this position is open to question. He then says that in the decided cases in which the claimant succeeded the sole shareholder was held personally liable only because of additional features, such as a showing of inadequate corporate capital or a showing that the claimant was misled. This generalization does not seem warranted by the cases.

“Arnold v. Phillips, Ixy F. 2d 497 (5th Cir. I94r), cert. denied, 313 U. S. 583 (I94I); Dixie Coal Mining Co. v. Williams, 221 Ala. 33I, I28 So. 799 ( 1930 ) (sole shareholder liable for compensation benefits to widow of corporate employee killed on the job). Cf. Hanson v. Bradley, 298 Mass. 371, Io N. E. $2 d 259$ (1937).

Worth noting in this connection is Section $67(d)(2)$ of the Bankruptcy Act, 30 STAT. 564 (1898), as 
It is eminently proper to require that the shareholder and incorporator must, as the price for the privilege of corporate personality and limited liability, finance the enterprise in such fashion as to enable it to meet the normal and expectable strains of a business of the size and character involved. ${ }^{45}$ Failure to honor this standard will impose upon him personal liability for obligations incurred in the execution of the business and will preclude his sharing as a creditor for sums advanced as loans to the business. ${ }^{46}$

Needless to say, the standard of adequate capital is slippery and difficult to apply. In recent years it has received much attention, especially in connection with the problem of subsidiary and affiliated corporations, as will appear below. A recent case in which the court was concerned with the application of this standard in a one-man company is Arnold v. Phillips. ${ }^{47}$ Here an entrepreneur who wished to operate a brewery formed a corporation with an authorized share capital of $\$ 50,000$ and paid cash for the shares. He then advanced $\$ 75,000$ as a loan in order to enable the company to begin business. The venture lost heavily. Two years after incorporation he advanced large sums as loans. Upon the subsequent insolvency of

amended, 54 STAT. 835 (I940), II U. S. C. $\$ 107$ (d)(2) (1946). This provision declares: "Evary transfer made and every obligation incurred by a debtor within one year prior to the filing of a petition in bankruptcy ... by or against him is fraudulent ... ; or (b) as to then existing creditors and as to other persons who became creditors during the continuance of a business or transaction, if made or incurred without fair consideration by a debtor who is engaged or is about to engage in such business or transaction, for which the property remaining in his hands is an unreasonably small capital, without regard to his actual intent; or (c) as to then existing future creditors, if mado or incurred without fair consideration by a debtor who intends to incur or believes that he will incur debts beyond his ability to pay as they mature. ..."

A similar provision is found in Section 5 of the Uniform Fraudulent Conveyance Act. 9 U. L. A. Sec. 5 (xgr8).

4 Fuller, supra note 43 , at 1382 : "It may not be unreasonable to expect that the requirement with respect to the relative amount of capital necessary to insure a sole shareholder against personal liability may be less exacting than when the parent-subsidiary relationship is involved, because the subsidiary corporation is really seeking a double insulation."

Note, Inadequately Capitalized Subsidiaries, ig U. of CHr. L. REv. 872 n. I (1952): "There appears to be no reason why a distinction should be made between parent corporations as stockholders and the stockholder in the 'one-man' corporation in the case of corporations organized with inadequate capital. However, liability appears to be more frequently limited when the stockholder is not a corporate cntity."

${ }^{\& B}$ Cases cited in note 44 , supra. In Hanson v. Bradley, 298 Mass. $37 x, 380,381,10$ N. E. $2 \mathrm{~d} 259$, 263-264 (1937), the court complained: "The original purpose of laws permitting the formation of corporations was to enable stockholders to put at the risk of the business capital reasonably adequate for its needs, and thereby keep free from that risk their uninvested assets and their personal responsibility.....

Incorporators have not always been satisfied to take even the limited risk just stated. They have sought to make available to general creditors, even to tort creditors, only an amount of capital which is either illusory or trifling compared with the business to be done, while the incorporators advance the capital really necessary for the business in the capacity of competing creditors, or even in that of secured creditors. In other words, they seek personal immunity without providing any fund to which creditors may resort. This is not unusual in the organization of corporations which are subsidiarics or affliates of others, but the practice is not confined to them."

${ }^{47}$ II7 F. 2d 497 (5th Cir. 194x), cert. denied 313 U. S. 583 (194I). The court said (p. 502): "It is not denied that a corporation, owned by one man save for qualifying shares, is lawful in Texas. That it was created to shield the owner from liability beyond the capital set up by the charter docs not show an unlawful or fraudulent intent, for that is a main purpose of every incorporation. It becomes an evidence of fraud only when the capital is unsubstantial and the risk of loss great, or the contributions to capital are greatly overvalued, and the like." 
the enterprise it was held that the first advance of $\$ 75,000$ should be treated as a capital contribution, not recoverable by him, but that the later advances should be treated as genuine loans, for which he could share as a corporate creditor. ${ }^{48}$

\section{E. Competing Equities of Personal and Business Creditors}

There has been occasion under the preceding headings to mention the respective positions of the personal creditors and the business creditors. The problem presents no difficulty when there are no circumstances calling for disregard of corporate personality. As already observed, the line of demarcation between the business unit and the shareholder's personal affairs serves to mark the respective positions of the shareholder, the business creditors, and the personal creditors. The corporate or business creditor cannot reach the shareholder's individual property; conversely, his personal creditors cannot reach the corporate property; the shareholder may share as a corporate creditor for sums loaned to the business; and it is immaterial to those results that insolvency has overtaken the shareholder, or the corporation, or both.

On the other hand, if there are circumstances calling for disregard of corporate personality, this problem of the respective positions of the personal and the business creditors presents great difficulty. Assuming that corporate personality is to be disregarded, the formal consequence is that "the corporation" vanishes and a sole proprietorship occupies the entire scene. The particular practical results would be: (I) the erstwhile sole or principal shareholder will not enjoy limited liability; (2) he will not be permitted to share as a corporate creditor and will be denied reimbursement for "loans" advanced to the business; and (3) all the assets remaining after secured or lien creditors have exhausted their security will constitute a common fund for the satisfaction of the unsecured claims held by the business and the personal creditors alike. There could be no quarrel with the first two results, but the third result may be open to question. When insolvency has overtaken the business venture, or the shareholder, or both, the competing equities of the personal and the business creditors may justify or require a marshaling of assets. It may be proper or necessary to give the business creditors priority in the business assets, and the personal creditors priority in the personal assets, or to make some other alignment, under the particular circumstances.

The point of the matter is that disregard of corporate personality is no open

${ }^{48}$ Anderson v. Abbott, 321 U. S. 349, 361, 362, 363 (1944): "Normally the corporation is an insulator from liability on claims of creditors. The fact that incorporation was desired in order to obtain limited liability does not defeat that purpose. . . . But there are occasions when the limited liability sought to be obtained through the corporation will be qualified or denied. Mr. Justice Cardozo stated that a surrender of that principle of limited liability would be made "when the sacrifice is essential to the end that some accepted public policy may be defended or upheld. . . . The cases of fraud make up part of that exception. . . . But they do not exhaust it. An obvious inadequacy of capital, measured by the nature and magnitude of the corporate undertaking, has frequently been an important factor in cases denying stockholders their defense of limited liability. ... That rule has been invoked even in the absence of a legislative policy which undercapitalization would defeat. It becomes more important in a situation such as the present one where the statutory policy of double liability will be defeated if impecunious bank-stock holding companies are allowed to be interposed as non-conductors of liability. It has often been held that the interposition of a corporation will not be allowed to defeat a legislative policy, whether that was the aim or only the result of the arrangement." 
sesame of solution. ${ }^{49}$ In the wake of disregarding corporateness there may be need of adjustments in order to resolve the conflicting equities of rival claimants. The lack of authority in these matters may indicate that the full implications of the problem have not been perceived. A more detailed analysis is found at the close of the succeeding discussion of the subsidiary corporation. The sentiments expressed regarding the analogous situation there presented are believed to be pertinent and controlling here.

An example which will serve to illustrate one aspect of this problem and to conclude the discussion is found in those cases where debtors resort to the one-man company or family corporation as a device to defraud creditors. A financially embarrassed merchant who wishes to hinder his creditors will sometimes form a close corporation, transfer the business to it, take in return all or most of the shares, and operate the business as a corporate officer at a fixed salary, with the dominion he enjoyed as a sole proprietor. In cases of this kind the courts disregarded corporate personality, of course, and permit the defrauded creditors to trace and seize the assets transferred. ${ }^{50}$ No one would question this result, standing by itself. However, consideration must also be given to those persons who have innocently dealt with and subsequently extended credit to the business on a corporate basis. There is authority indicating that these subsequent creditors will enjoy priority in the corporate assets over the former creditors whom the incorporator sought to defraud.51 On the other hand, if the former creditors act promptly and through legal action acquire a lien on the assets transferred to the corporation, before the new corporate creditors acquire such a lien, the former creditors' prior lien will prevail. ${ }^{52}$ Thus, the position of the defrauded creditors will depend on the diligence with which they have followed their debtor's affairs and the timeliness with which they have moved. The respective equities of the two groups of creditors are adjusted by favoring the new creditors over the old creditors unless the latter have been active and alert.

The good faith or innocence of a claimant is even more important than his diligence. For example, in the Sampsell case ${ }^{53} X$, a financially embarrassed sole pro-

${ }^{10}$ Elvin R. Latty, Subsidiaries and Affiliated Corporations 7 (1936): ". . even when the point of 'disregarding' the entity is once reached, this 'disregard' may leave one only at the threshold of the solution to the problem under consideration."

${ }^{50}$ Bennett v. Minott, 28 Ore. 339, 39 Pac. 997, 44 Pac. 283 (1896); Kellogg v. Douglas County Bank, 58 Kan. 43 (I897); First National Bank of Chicago v. Trebein Co., 59 Ohio St. 3 I6, 52 N. E. $834(1898)$. In the case last cited the court said (p. 837): "The corporation was in substance another F. C. Trebein. His identity as owner of the property was no more changed by his conveyance to the company that it would have been by taking off one coat and putting on another." In another case it is said that "such a corporation is a mere parasitic growth, a mass of fungus, which will be lopped off clean whenever necessary to sound results." Matchan v. Phoenix Land Investment Co., 159 Minn. 132, 138, 198 N. W. 417, 420 (1924).

${ }^{51}$ See Jackson v. N. H. Thomas Investment Co., 46 F. 2d 252 (5th Cir. I93I); Folsom \& Co. v. Detrick Fertilizer Co., 85 Md. 52, 36 Atl. 446 (1897).

Sampsell v. Imperial Paper \& Color Corp., 3I3 U. S. 215 (I94I), takes a different position, though the decision itself is easily distinguishable on other grounds. Here the corporate creditor knew all the material facts when his claim arose; indeed, he had helped in the formation of the corporation and was in effect a party to the fraud.

s2 Booth v. Bunce, 33 N. Y. I39 (1865).

${ }^{63}$ Sampsell v. Imperial Paper \& Color Corp., 313 U. S. 215 (194I). 
prietor, transferred his assets to a family corporation formed for the purpose of hindering his creditors. $Y$ extended credit to the corporation with full knowledge of these facts. Upon the subsequent bankruptcy of $X$ the court ordered the seizure of the corporate assets as part of $X$ 's bankrupt estate. $Y$ contended that in the distribution of the corporate assets he was entitled to priority over the individual creditors whom $X$ had sought to defraud. Y's claim for priority was denied. This seems a fair result. Under the circumstances presented the equity of the shareholder's defrauded individual creditors was stronger than that of the corporate creditor.

Similarly, in Hanson $v$. Bradley ${ }^{54}$ an employee of a one-man company which had been formed with nominal capital and was insolvent sought to hold the sole shareholder personally liable for wage claims. The court held the employee could not succeed, since he was fully aware of all the facts when his claim arose. ${ }^{55}$

II

The Subsidiary Corporation ${ }^{56}$

Although the subsidiary corporation has been most extensively used, and has reached its acme of evolution, in the field of public utilities, it has been widely used in other areas of commercial endeavor. ${ }^{57}$ Among the many reasons for its adoption and use are: the desire for greater facility in financing, the avoidance of taxation, and the elimination of cumbersome management structures. ${ }^{58} \mathrm{~A}$ basic factor has

E* 298 Mass. 37I, to N. E. 2d 259 (1937).

55 The shareholder had advanced funds as a loan to the corporation and had taken a lien on the corporate assets as sccurity for repayment. The employee was also seeking to set aside this lien, but did not succeed.

In its opinion the court first delivers a general condemnation of arrangements to form corporations with inadequate capital, and then says (298 Mass. at 382, I0 N. E. 2 d at 264): "The plaintiff was not wronged by the fact that the corporation was organized with a trifling capital and could not live except upon borrowed money; nor by the fact that the lenders insisted on security. He knew the essential facts and accepted the situation."

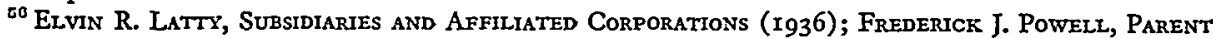
and Substiary Corporations (i93i).

The provocative study by Latty is now the classic in the field and has become the Mecca of courts and commentators. Latty makes great sport of the business of lifting and piercing veils and the other verbal artifices of the courts, which fail to articulate the policy factors that constitute the causal core of decision. He well recognizes, of course, that the decisional structure erected by the judges is sound and commendable, despite the verbal shabbiness of its façade. He says (p. 3): "While the decisions have on the whole been an admirable feat of social engineering, their rationalizations have been in terms of mechanical formulae which fail when put to the test, and which do not reveal the real dynamic forces at work."

${ }^{57}$ Mr. Justice Jackson, dissenting, in Anderson v. Abbott, $32 \mathrm{I}$ U. S. 349, 379-380 ( $x 944$ ): "If to legislate were the province of this Court, we would be at liberty candidly to exercise discretion toward the undoing of the holding company. Some of us feel that as utilized in this country it is, with a few exceptions, a menace to responsible management and to sound finance, shifting control of local institutions to absentee managements and centralizing in few hands control of assets and enterprises bigger than they are able well to manage-views which are matters of record." See Berle, The Developing Law of Corporate Concentration, ig U. OF CHr. L. Rev. 639 (I952).

${ }_{\text {z8 }}^{8}$ The process of multiple incorporation is used to split up a business into its component parts. For instance, the enterprise of producing and selling a given item may be divided into the manufacture of the product and the marketing of the product. Thus, a corporation formed in Ohio for the purpose of manufacturing and selling tires causes the formation of a subsidiary in Delaware. The parent then manufactures tires and sells them only to the subsidiary, which in turn markets them to the public. McLean v. Goodyear Tire \& Rubber Co., Inc., 85 F. 2d 150, 151 (5th Cir. 1936): "The Ohio 
been the wish to avoid the difficulty or the impossibility of a concern's qualifying as a foreign corporation in a given state. A corporation formed in one state, and wishing to do business in another state, may find it either convenient ${ }^{50}$ or necessary ${ }^{60}$ to have a subsidiary formed in the latter state for this purpose.

A potent, though not a paramount, motive for the use of the subsidiary corporation has been the desire for limited liability. An individual who wishes to avoid the risk of submitting his entire fortune to the vicissitudes of a business may incorporate and may, through the limited liability thus attained, dedicate only a portion of his estate to the venture. In the same way, a corporation which wishes to risk only a portion of its assets in a particular sphere of the business may form a subsidiary for this purpose and may, through the additional limited liability thus attained, dedicate only a portion of its assets to that particular segment of the business. So, by the process of further incorporation there is obtained further insulation from liability.

\section{A. The Parent and Subsidiary as Separate Units}

Two factors appear as constants in the parent-subsidiary relationship: (r) The parent corporation owns all, or a majority of, or a controlling interest in the subsidiary's shares. Sometimes the same persons own all, or a majority of, or a controlling interest in the shares of both corporations. (2)Both corporations have common, or identical, directors and officers.

The presence of these two factors is not of itself sufficient ground for disregarding the separate corporate personalities of the two units. The parent and subsidiary are treated as separate and distinct persons, pursuant to the legal entity theory, even though the parent owns all the subsidiary's shares and the two corporations have identical directors and officers. ${ }^{61}$ In the language of a typical judicial declaration: ${ }^{22}$

corporation had the right to create the subsidiary for the purpose of dividing its business and . . . for the purpose of its usual business, not involving fraud or infringement upon the rights of third parties, they are to be considered separate entities." So, a corporation formed for the purpose of manufacturing rubber products may decide to become a mere holding company and lease its various planta to at subsidiary organized for the purpose of operating them. Sce U. S. Rubber Co. v. Query, Ig Fed. Supp. Igr (D. S. C. 1937).

${ }^{50}$ For example, suppose a Maine corporation wishes to do business in Alabama and discovers that the latter bestows on its corporations certain advantages not enjoyed by corporations formed elsewherc. In order to reap the benefit of these advantages, the corporation does not enter Alabama as a forcign corporation, but instead has a subsidiary formed in that state for the purpose of doing local busincss there. See Cannon Mfg. Co. v. Cudahy Packing Co., 267 U. S. 333, 335, 336, 337 (I925).

${ }^{60}$ For example, a Vermont railroad company wishes to join to its line a roadbed lying in Massachusetts, but the law of that state requires that railroads in the state must be operated by its own corporations. The Vermont company thereupon has a subsidiary formed in Massachusetts to operate the roadbed there. See Central Vermont Ry. v. Southern New England R. R., I Fed. Supp. ro04 (D. Mass. 1932). Similarly, Mexican law forbids foreign corporations to operate oil wells within fifty kilometers of the coast. An American corporation wishing to operate free of this restriction simply resorts to the device of organizing a string of Mexican subsidiaries manned by Mexican officers. See New York Trust Co. v. Island Oil \& Transport Corp., 34 F. 2d 655 (2d Cir. I929). See also notes 72 and 73, infra.

${ }^{\circ 1}$ Dabney v. Chase National Bank of City of New York, 98 F. Supp. 807 (S. D. N. Y. 1951). Cf. Bigelow v. R. K. O. Radio Pictures, Inc., 170 F. $2 d 783$ (7th Cir. 1949), noted in 33 Mano. L. Rev. 123 (1949). See Albert v. MeGrath, ro4 F. Supp. 89x, 897 (S. D. Cal. 1952).

${ }^{02}$ Commerce Trust Co. v. Woodbury, 77 F. 2d 478, 487 (8th Cir. 1935). For similar language sec 
Few questions of law are better settled than that the corporation is ordinarily a wholly separate entity from its shareholders, whether they be one or more. ... Likewise we think it must be conceded that neither ownership of all of the stock of one corporation by another, nor the identity of officers in one with officers in another, creates a merger of the two corporations into a single entity, or makes one either the principal or the agent of the other.

Ownership of shares in a corporation normally carries with it certain rights, such as the right to vote for directors, to adopt by-laws, to vote on fundamental changes, and so forth. These rights are, as a matter of verbal convenience, bundled together under the name-tag of "control." The fact that a parent corporation, in its character as sole or majority shareholder of the subsidiary, acquires and exercises such control does not assimilate the two units. After all, this control is merely an incident of the ownership of shares and is recognized by law as a normal matter of corporate procedure, A corporate shareholder is entitled, no less than a human shareholder, to exercise the control which shareholdership carries. ${ }^{63}$

It is frequently held, in keeping with these principles, that the parent corporation is not liable for the contracts and torts of the subsidiary, even though the former holds all the latter's shares and the directors and officers of both corporations are the same. ${ }^{64}$ Conversely, the subsidiary is not liable for the contracts and torts of the parent corporation. ${ }^{65}$

In the same way, the parent and subsidiary are frequently regarded as separate units for other legal purposes, such as determining the incidence of taxation ${ }^{66}$ and

Garden City Co. v. Burden, I86 F. 2d 65I, 653 (Ioth Cir. I95I); Henderson v. Rounds \& Porter Lumber Co., 99 F. Supp. 376, 381 (W. D. Ark. 195I); Centmont Corp. v. Marseh, 68 F. 2d 460, 463 (rst Cir. 1933); Martin v. Development Co. of America, 240 Fed. 42, 45 (9th Cir. rgr7).

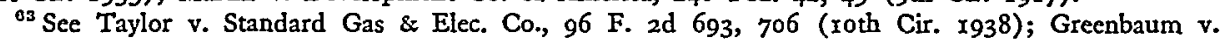
Lehrenkrauss Corp. 73 F.2d 285 (2d Cir. I934); Exchange Bank of Macon v. Macon Construction Co., 97 Ga. I, 6, 25 S. E. 326, 328 (1895): "Tt makes no difference in principle whether the sole owner of the stack of a corporation is a man or another corporation. The corporation owning such stock is as distinct from the corporation whose stock is so owned as the man is from the corporation of which he is the sole member."

ot Constitution Publishing Co. v. Dale, I64 F. 2 d 210 (5th Cir. 1947) (tort); Kulukundis v. Dean Stores Holding Co., Inc., I32 Conn. 685, 47 A. $2 \mathrm{~d} \times 83$ (I946) (rent due on subsidiary's lease); Ohio Edison Co. v. Warner Coal Corp., 79 Ohio App. 437, 72 N. E. 2d 487 (I946) (contract claim); North v. The Higbee Co., I3I Ohio 507, 3 N. E. $2 d$ 39r ( 1936 ) (rent due on subsidiary's lease); Owl Fumigating Corp. v. California Cyanide Co., 24 F. $2 d$ 718 (D. Del. 1928), affd, 30 F. $2 d 812$ (3rd Cir. 1929) (patent infringement by subsidiary); Majestic Co. v. Orpheum Circuit, Inc., 2I F. 2d 720 (8th Cir. r927) (rent due on subsidiary's lease); Pagel, Horton \& Co. v. Harmon Paper Co., 236 App. Div. 47, 248 N. Y. Supp. x68 (4th Dep't 1932) (supplies purchased by subsidiary). See American Cyanamid Co. v. Wilson \& Toomer Fertilizer Co., 51 F. 2d 665 (5th Cir. I931); Finley v. Union Joint Stock Land Bank of Detroit, 28r Mich. 214, 274 N. W. 768 (1937).

"G McLean v. Goodyear Tire \& Rubber Co., Inc., 85 F. 2d I50 (5th Cir. 1936); Kingston Dry Dock Co. v. Lake Champlain Trans. Co., 3I F. 2d 265 (2d Cir. I929). Cf. The J. B. Austin, Jr., I F, 2d 451 (D. N. Y. I924). For a discussion of this point see Note, 43 YALE L. J. 472 (1934).

${ }^{\circ O}$ See Commissioner of Internal Revenue v. Oxford Paper Co., 194 F. 2d 190 (2d Cir. 1952); Warrior River Terminal Co. v. State, 58 So. 2d roo (Ala. I952); Rexall Drug Co. v. Peterson, 248 P. 2d 433 (Cal. App. I952); Commonwealth v. Gulf Oil Corporation, 359 Pa. 583 , 60 A. 2 d 46 (I948). Cf. Superior Coal Co. v. Department of Finance, 377 Ill. 282, 36 N. E. 2 d 354 (I94I). In U. S. Rubber Co. v. Query, 19 F. Supp. rgr (E. D. S. C. 1937), a New Jersey corporation owned various plants throughout the country, including one in South Carolina. These plants were leased to and operated by a subsidiary formed for the purpose in Delaware. In deciding that the New Jersey holding 
settling problems of judicial jurisdiction and service of process. ${ }^{67}$ Likewise, it is held that a person employed by a subsidiary is not an employee of the parent corporation. $^{68}$

\section{B. Fusion of Parent and Subsidiary}

The rules previously discussed concerning disregard of corporate personality are, of course, applicable to the parent-subsidiary relation. ${ }^{69}$ It is clear that corporate personality will be disregarded, and the two units will be "fused," wherever "the notion of legal entity is used to defeat public convenience, justify wrong, protect fraud, or defend crime."70

company was not doing business in South Carolina and was not subject to a franchise tax imposed by that state, the court said (p. I94): "Through stock ownership, interlocking dircctorates and identity of controlling officers, plaintiff controls the Rubber Products Company. The two corporations occupy the same offices in New York City, but each maintains its separate corporate identity, the persons who are officers performing for each corporation the duties pertaining to their offices in that corporation, and transactions between the two corporations being accurately recorded in their corporate books and records."

${ }^{07}$ For example, a corporation formed in state $A$ has a subsidiary formed in state $B$ for the purpose of doing local business in state $B$. The parent corporation is not considered to be doing business in, and is not subject to suit in, state B. Cannon Mfg. Co. v. Cudahy Packing Co., 267 U. S. 333 (1925); La Varre v. International Paper Co., 37 F. $2 d$ I4I (D. S. C. 1929); Missouri-Kansas Pipe Line Co. v. Hobgood, $244 \mathrm{Ky}$. 570, 5x S. W. 2d 920 (1932).

Service of process upon a local subsidiary is not equivalent to service of process upon the forcign parent. Steinway v. Majestic Music Co., I79 F. 2d 68I (roth Cir. 1949). Sec Mas v. Nu-Grape Co. of America, 62 F. 2d II3 (4th Cir. 1932). The problem is discussed in Note, 45 ILL. L. REV. 29I (I950).

The result is otherwise if the subsidiary is a mere "agency" or "instrumentality" of the parent. In that event, the business done in the state by the subsidiary is held to render the parent present in the state and to subject it to suit there. Society Milion Athena v. National Bank of Greece, 166 Mise. 190, 2 N. Y. Supp. 2d 155 ( 9937 ), $a f^{\prime} d, 253$ App. Div. 650, 3 N. Y. 2d 677 (Ist Dep't 1938). See also Industrial Research Corp. v. General Motors Corp., 29 F. 2d 632 (D. Ohio 1928); Williams v. Frecport Sulphur Co., 40 S. W. $2 d 8$ I7 (Tex. Civ. App. 193I), 30 Mícr. L. Rev. 464 (1932).

${ }^{8}$ Wheeler v. New York, N. H. \& H. R. R., II2 Conn. 5 ro, I53 Atl. I59 (193I). Accord: Press Co., Inc. v. National Labor Relations Board, II 8 F. 2d 937 (D. C. Cir. 1940), cert. denied, $3^{13}$ U. S. 595 (Ig4I). Cf. Bethlehem Steel Co. v. National Labor Relations Board, 120 F. 2d 64I (D. C. Cir. I94I).

${ }^{\circ 9}$ Indeed, the leading American decision concerning disregard of corporate personality was precisely one involving a parent corporation and its subsidiary. United States v. Milwaukee Refrigerator Transit Co., 142 Fed. 247 (D. Wis. I905). Here it was found that a brewing company had formed a subsidiary transit company in order to obtain shipping rebates from railroads, in violation of federal law, and the federal government's request for an injunction breaking up the practice was granted. Accord: Federal Gravel Co. v. Detroit \& Machinac Railway, 248 Mich. 49, 226 N. W. 677 (1929).

Nashville, C. \& St. L. Ry. v. Faris, I 66 Tenn. $238,244,60$ S. W. $2 d 425,426-427$ (1933): "No principle of law is better settled than that which holds that where a corporation resorts to the subterfuge of creating a 'dummy' corporation to be used as its agency or instrumentality, for the purpose of avoiding liability or furthering its illegal designs, they will be treated as one and the same."

Dabney v. Chase National Bank of City of New York, 98 F. Supp. 807, 837 (S. D. N. Y. 195I): "The law with respect to ignoring the corporate fiction is clear in its insistence upon factors indicating such a unity of relationship among formally independent corporate entities that an adherence to the principle of separate existence would work a fraud or other injustice."

A special aspect of this problem is discussed in Note, Distegarding Separate Corporate Entities to Preserve an Integrated Economic Structure, 47 Cot. L. Rev. 109 (1947).

${ }^{70}$ See note 33 , supra. In Rippel v. Kaplus, 124 N. J. Eq. 303, I A. 2 d 883 (Ch. 1938), confirma. tion of a mortgage foreclosure sale was opposed by the mortgagor, a corporation, on the ground that the latter was a helpless and penniless debtor unable to protect itself by bidding at the sale. All the shares ot the mortgagor were owned by another corporation, and there was nothing to show that the latter was financially unable to satisfy the mortgage. The court confirmed the sale and remarked (124 N. J. Eq. at 305, I A. $2 \mathrm{~d}$ at 884): "This is a case in which the corporate entity of the obligor should be disregarded; it is not an appeal of a distressed and helpless debtor." See Seymour v. Woodstock \& Sycamore 
This brief statment will serve as sufficient preface to two particular problems in which disregard of corporate personality has special significance in the parent-subsidiary pattern.

The first of these concerns the subsidiary which is formed in order to overcome a legal restriction imposed by a given jurisdiction. 'The legislature of a state will sometimes declare that certain activities (such as operating a railroad, drilling oil wells, acquiring land by eminent domain) may be carried on within the state only by its own domestic corporations. ${ }^{71}$ A foreign corporation wishing to engage in these activities in that state will simply resort to the practice of organizing a subsidiary in that state for this purpose. There is a striking Arkansas decision holding that this practice is not successfully impeachable as an evasion and that the parent corporation is entitled to retain the advantage thus sought and secured. ${ }^{\mathbf{2}}$ There is also authority to the contrary. ${ }^{73}$

No doubt the result in a given case will depend on the nature and purpose of, and the judicial attitude towards, the restriction in question. The local courts may consider the restriction relatively trifling or parochial; on the other hand, they may consider it one which serves a desirable policy. It would be an easy matter for the court to sanction the parent's conduct in the first case, and to condemn the parent corporation for evasion in the second case. The "well established" theory of corporate entity will serve as the rationalizing peg in the first case, and the equally "well

Traction Co., 28r Ill. 84, II7 N. E. 729 (I9I7), 3I HARv. L. Rev. 894 (I9r8). In Rapid Transit Subway Construction Co. v. City of New York, 259 N. Y. 472, I82 N. E. I45 (1932), the plaintiff, a corporation, sued the City of New York to recover damages for breach of contract. It was shown that the breach was attributable to the conduct of another corporation which owned all the shares of the plaintiff. The court denied recovery and said (259 N. Y. at 49I, I82 N. E. at $\times 5 \mathrm{I}$ ): "Exemption from liability for wrong committed by the corporation whose stock it owns is inherent in the privilege, accorded to it by law, of conducting its business in corporate form: exemption from the consequences of its own acts working injustice upon parties with which it deals is a perversion of that privilege."

${ }^{71}$ See note 60 , stupra, and notes 72 and 73 , infra.

${ }^{72}$ Patterson Orchard Co. v. Southwest Arkansas Utilities Corp., I79 Ark. 1029, I8 S. W. 2d 1028 (1929): A corporation was formed in Arkansas, took land by eminent domain there, and leased the land to a Delaware corporation. The Arkansas company was formed as a subsidiary of the Delaware company in order to acquire the land, since the constitution of Arkansas denied foreign corporations the privilege of eminent domain and rendered the Delaware company powerless to obtain the land for itself directly. The court upheld the transaction, over the objection of the party whose land had been thus condemned and acquired. The court (p. I032) conceded that "There are, perhaps, some unusual circumstances connnected with this case," but concluded that the contestant had not been "defrauded in any way" and that the Delaware company had merely resorted to a proper legal device to obtain the right-of-way which it thought necessary for the conduct of its business and which it had been unable to obtain by any other method from the appellant." See Irvine Co. v. Bond, 74 Fed. 849 (S. D. Cal. 1896).

${ }^{73}$ State v. Safford, II7 Ohio 576,582 , I59 N. E. 829, 830-83I (I927): "The principle of denying the right to do by indirection what cannot be done by direct method is thus clearly recognized. If a non-resident insurance company cannot write insurance in Ohio without a resident license, how can this desired result be acquired by coming into the state in the guise of an owner of a controlling interest in a domestic corporation, thus seeking to circumvent the statute relative to resident licenses?" Cf. New York Trust Co. v. Island Oil \& Transport Co., 34 F. 2d 655 (2d Cir. 1929); Central Vermont Ry. v. Southern New England R. R., I Fed. Supp. ro04 (D. Mass. I932); General Motors Acceptance Corp. v. Commissioner of Banks, 258 Wis. 56,45 N. W. $2 \mathrm{~d} 83$ (I950), noted in 5 VAND. L. REv. 637 (1952). 
established" rule for disregarding corporate personality will serve to justify the decision in the second case.

Much more important for present purposes is the second particular problem mentioned above. This problem is the matter of the legal and financial criteria which are to govern the operations of a parent corporation and its subsidiary.

The activities of a parent corporation and its subsidiary should conform to the following four standards: ( $\mathrm{x}$ ) Adequate financing of the subsidiary as a separate unit. The subsidiary should be established as a separate unit sufficiently financed to meet the normal obligations and usual strains expectable in a business of its size and character. (2) Sedulous avoidance of intermingling. The business transactions of the two units should be kept distinct; separate accounts and records should be maintained. (3) Careful observance of the formalities of separate corporate procedures. The formal distinction between the two boards of directors and two sets of officers should be honored, even though the directors and officers of both corporations are the same persons; the formalities of separate corporate action, such as the ritual of separate meetings, should be fully observed and the dual capacities of the directors and officers thus kept defined. (4) Avoidance of representations blurring the division between the two units. The two units should not be held out to the public as being merely one. ${ }^{74}$

When these standards are observed, a parent and its subsidiary will normally be treated as separate entities, and the obligations and liabilities of the one will be kept distinct from those of the other, in accordance with the principles already discussed. A failure to honor one or more of these requirements may be fatal. The court may disregard corporate personality and consider the parent and subsidiary "assimilated" for legal purposes. ${ }^{75}$ Consequently, liability may be imposed on the parent for contracts and torts of the subsidiary. ${ }^{76}$

Three well known cases which supply illustrative contour to the problem may be briefly considered.

The first case is Luckenbach S. S. Co., Inc. v. W. R. Grace \& Co., ${ }^{77}$ decided in Ig20 by the United States Court of Appeals for the Fourth Circuit. Here a corporation capitalized at $\$ 800,000$ rented its fleet of steamers to a subsidiary, capitalized at $\$ 10,000$, for the purpose of operating the vessels. Both corporations had the same officers and 90 per cent of the shares in each corporation were held by the person who was president and general manager of both units. The parent was held liable for a breach of contract by the subsidiary, since "it would be unconscionable to allow the owner of this fleet of steamers, worth millions of dollars, to escape liability be-

\footnotetext{
${ }^{2}$ This analysis is made in Douglas and Shanks, Instulation from Liability Through Subsidiary Corporations, 39 YALE L. J. I93, 196 ff. (1929).

${ }^{75}$ Fish v. East, $x 14$ F. 2d I77 (roth Cir. I940); Pacific Can Co. v. Hewes, 95 F. 2 d 42 (9th Cir. 1938); Herman v. Mobile Homes Corp., 317 Mich. 233, 26 N. W. 2d 757 (1947).

${ }^{70}$ Cases cited in the following six notes. Other consequences which ensue upon assimilation of the two units are discussed under subsequent headings in the text. See also note 67 , supra.

${ }^{77}{ }_{27}$ Fed. 676 (4th Cir. 1920).
} 
cause it had turned them over a year before to a $\$$ Io,000 corporation which is simply itself in another form."78

The second case is Ross $v$. Pennsylvania $R . R_{.,}{ }^{79}$ decided in 1930 by the New Jersey courts. Here a person was struck and killed in New Jersey by a negligently operated train of West Jersey \& Seashore Railroad Company, which employed and paid the wages of the engineers and the other members of the train crew. This company was a subsidiary of the Pennsylvania Railroad Company. The name "West Jersey and Seashore R. R. Co.," formerly on the fenders of the locomotive, had been removed and the word "Pennsylvania" substituted; the word "Pennsylvania" appeared on the coaches of the train; the letters "P. R. R." appeared on the uniforms of some of the crew; a time table captioned "Pennsylvania Railroad System" listed the train on the schedules therein contained. The decedent's administrator wrote two letters concerning the accident to the Pennsylvania Railroad Company and the latter's district claim agent answered both on the merits. In a suit by the administrator to recover damages from the Pennsylvania Railroad Company, the lower court submitted to the jury the issue whether that company was controlling and operating the train at the time of the accident. The jury returned a verdict for the plaintiff, and the lower court entered judgment on the verdict. On appeal it was held proper to submit the issue to the jury and the judgment was affirmed. ${ }^{80}$

The third case is Costan v. Manila Electric Co., ${ }^{81}$ decided in 1928 by the United States Court of Appeals for the Second Circuit. Here Manila Electric Company held title to and operated a street railway in Manila. All its shares, excepting those necessary to qualify directors, were held by Manila Electric Corporation. The directors of the latter, acting through a committee, appointed a party to act as manager of the Manila property and conferred upon him broad powers (hiring of employees, purchase of supplies, and so forth), subject to "such general supervision and control as may be exercised by the directors" of the parent company. This manager was to receive $\$ 25,000$ for his services- $\$ 5,000$ from the parent, $\$ 20,000$ from the subsidiary. While this arrangement prevailed, a person was injured by the negligent operation of a car on the Manila Street Railway. He sued the holding company for damages. It was held that the lower court committed reversible error in entering a compulsory nonsuit. Liability may be fixed on the parent corporation because by an obtrusive act of intervention it entrusted complete control over the subsidiary's property to a third party who was subject only to the will of the parent's directorate.

${ }^{78} 267$ Fed. at 68r. Accord: Wallace v. Tulsa Yellow Cab Taxi \& Baggage Co., 6r P. 2d 645 (Okla. 1936); Garden City Co. v. Burden, x86 F. 2d 65I (roth Cir. 195I) (tort claim based on subsidiary's negligent operation of an irrigation canal); Henderson v. Rounds \& Porter Lumber Co., 99 F. Supp. 376 (W. D. Ark. I95I) (contract claim). See Herman v. Mobile Homes Corp., 3x7 Mich. 233, 26 N. W. 2d 757 (I947) (contract claim).

70 Io6 N. J. L. 536, 148 Atl. 74 I (1930), 43 HARv. L. REv. II54 (I930).

${ }^{80}$ Accord: Mangan v. Terminal Transportation System, Inc., I57 Misc. 627, 284 N. Y. Supp. 183 (Sup. Ct. 1935). See Weisser v. Mursam Shoe Corporation, I27 F. 2d 344 (2d Cir. I942); Davis v. Alexander, 269 U. S. I14, II7 (1925). Cf. Berkley v. Third Avenue Railway, 244 N. Y. 84 , I55 N. E. 58 (1926); Bergenthal v. State Garage \& Trucking Co., I79 Wis. 42, 190 N. W. 90r (1922).

${ }_{24}$ F. $2 \mathrm{~d}_{383}$ (2d Cir. 1928 ). 
And the subsidiary, without part in the plan, is saddled with an obligation of $\$ 20,000$ to boot. $^{82}$

The Costan case indicates that the result in a given situation may turn on formal aspects of "control." The parent corporation's control, exercised as a normal legal incident of shareholdership and through the usual rituals of discrete corporate procedures, is one thing. Dominion exercised by the parent over the subsidiary's affairs in a "direct" or "obtrusive" manner is another thing. The former is judicially sanctioned, with the consequence that the separate corporate personality of each unit is sustained. The latter is judicially condemned, with the consequence that corporate personality will be disregarded and the two units will be assimilated.

Justice Learned Hand, incomparable for his sense of the practical in litigation, has neatly capped the matter in these words: $:^{83}$

Control through the ownership of shares does not fuse the corporations, even when the directors are common to each. One corporation may, however, become an actor in a given transaction, or in part of a business, or in a whole business, and, when it has, will be legally responsible. To become so, it must take immediate direction of the transaction through its officers, by whom alone it can act at all. . . . liability normally must depend upon the parent's direct intervention in the transaction, ignoring the subsidiary's paraphernalia of incorporation, directors, and officers. The test is, therefore, rather in the form than in the substance of the control, in whether it is exercised immediately, or by means of a board of directors and officers, left to their own initiative and responsibility in respect of each transaction as it arises. Some such line must obviously be drawn, if shareholding alone does not fuse the corporations in every case.

In concluding this discussion of the four standards which should govern intercorporate behavior special mention must be made of the matter of adequate

82 The court said (pp. 384-385): "The manager's actions are made subject only to such general supervision as may be exercised by the directors of the holding company, not of the subsidiaries whose properties are to be operated. In short, the holding company utterly disregards the Manila Electric Company as a distinct corporate entity, except perhaps for bookkeeping purposes, and deals with its properties and their operation as a street railway exactly as though the legal title were in the holding company."

Accord: McCarthy v. Ference, $358 \mathrm{~Pa} .485,58$ A. 2d 49 (1948) (tort claim based on subsidiary's negligent maintenance of property). Here the court said (358 $\mathrm{Pa}$. at $489,58 \mathrm{~A}$. $2 \mathrm{~d}$ at 56 ): "It appears that at all times the Steel Corporation treated the Land Company as nothing more than a department of its own business; indeed it showed its complete disregard of any autonomy on the part of the Land Company by ignoring it entirely in the contracts which it entered into with the Railroad Company and the County; the Land Company had nothing whatever to do with the entire project, nor did it enter as an independent body into any of the negotiations or plans connected therewith."

Consolidated Rock Co. v. Du Bois, 312 U. S. 5ro, 523-524 (194I): "All managcment functions of the several companies were assumed by Consolidated. The subsidiaries abdicated. Consolidated operated them as mere departments of its own business. Not even the formalities of separate corporate organizations were observed except in minor particulars such as the maintenance of certain separate accounts. In view of these facts, Consolidated is in no position to claim that its assets are insulated from such claims of creditors of the subsidiaries. To the contrary, it is well settled that where a holding company directly intervenes in the management of its subsidiaries so as to treat them as mere departments of its own enterprise, it is responsible for the obligations of those subsidiaries incurred or arising during its management. ... A holding company which assumes to treat the properties of its subsidiarics as its own cannot take the benefits of direct management without the burdens."

${ }^{83}$ Kingston Dry Dock Co. v. Lake Champlain Transp. Co., 3I F. 2d 265, 267 (2d Cir. 1929). Sce Taylor v. Standard Gas \& Elec. Co., 96 F. 2d 693, 706 (10th Cir. 1938). 
capitalization. This standard is by all odds the most important of the four, and doubtless the most elusive. It impresses the courts and weighs heavily in the judicial balance. ${ }^{84}$ In recent years it has received increasing attention from the courts and writers. ${ }^{85}$ Cases concerning the problem may be grouped, for convenience and merely as an aid to discussion, into three loose categories:

(I) Cases in which the subsidiary is formed with a nominal or trifling capital. Here it is common to find that the subsidiary, at the very start of its existence, has few or no assets and requires financial support for its operations. It lacks even a "minimal credit or cushion."

(2) Cases in which the subsidiary is formed with capital which is more than nominal, but which is insufficient to meet the expectable strains of a business of its size and nature.

(3) Those cases which fall under either of the first two categories and, in addition, reveal a plan to milk the subsidiary for the parent's benefit.

Cases of the first category have been easy to decide. An example is a recent case in which the subsidiary, formed to engage in the business of building homes on a large scale, was capitalized at $\$ 5000$ and immediately embarked on a project requiring a credit of $\$ 1,000,000 .^{86}$

Cases of the third category have also been easy to decide. A recent example is found in Henderson v. Rounds \& Porter Lumber Co. ${ }^{87}$ Here a subsidiary was created to manufacture lumber products. It sold these items below market price to the parent. The constant operating loss which resulted led to bankruptcy, even though the parent made several advances (as secured loans) to the subsidiary. The court found that the capital with which the subsidiary started $(\$ 30,000$ and machinery) was sufficient for normal operations and that, in the absence of the milking by the parent, the subsidiary could have prospered, because of the great demand and high prices in the lumber products market at the time. The court concluded that under the circumstances the subsidiary should be regarded as "undercapitalized from

84 Douglas and Shanks, Insulation Fron Liability Through Subsidiary Corporations, 39 Yale L. J. 193, 214 (1929): “. . . courts are more impressed by an obvious inadequacy of capital on the part of the subsidiary than they are by the presence of any of the other indicia of identity between the corporations. ... In fact, sufficient capital and adequate financial arrangements or the lack of it, insofar as the various factors motivating the courts are capable of ascertainment from the cases, in some instances seems to be largely determinative."

${ }^{85}$ See Elvin R. Latty, Subsidiary and Affiliated Corporations iro-r4r (1936); Rembar, claims Against Affiliated Companies in Reorganization, 39 CoL. L. Rev. 907, 915 ff. (1939); Krotinger, The Decp Rock Doctrine: A Realistic Approach to Parent-Subsidiary Law, 42 CoL. L. Rev. II24, I129ff. (1942). A well considered recent discussion, bricf and to the point, is found in Note, Inadequately Capitalized Subsidiaries, 19 U. OF CHr. L. Rev. 872 (1952).

${ }^{80}$ Herman v. Mobile Homes Corp., 317 Mich. 233, 26 N. W. 2d 757 (1947) (parent held liable for subsidiary's contractual obligations). Sce also the Wallace and Garden City cases, both cited in note 78 supra. In contrast, consider the case of Ohio Edison Co. v. Warner Coal Corp., 79 Ohio App. 437, 72 N. E. 2d 487 (1946), in which the court, holding that the parent was not liable for the subsidiary's debt, said of the subsidiary (79 Ohio App. at 439, 72 N. E. 2 d at 488): "It operated the business of mining the coal and had a substantial capital reasonably regarded as adequate to enable it to operate its business and pay its debts as they matured. Various unforeseen economic factors intervened to defeat the expectation."

${ }^{87} 99$ F. Supp. 376 (W. D. Ark. 195I). 
the start." Accordingly, the parent was held liable to the subsidiary's creditors. ${ }^{88}$

The Luckenbach case, already considered above, may be regarded as a decision falling within the second category. That case seems clear on its facts and was apparently easy to decide. It is obvious, however, that the problem of determining adequacy of capitalization in cases of the second category may present great diffculty.

The matter of adequate versus inadequate capitalization arises frequently in cases where the parent seeks to share as a creditor for advances made to the subsidiary. These cases present the question whether the parent's advances are to be treated as genuine loans, for which the parent may share as a creditor of the subsidiary, or merely as contributions to the subsidiary's capital, for which the parent's claim must be subordinated to the claims of the subsidiary's creditors. ${ }^{80}$ Various tests have been suggested as aids to the determination of this question. ${ }^{90} \mathrm{~A}$ principal feature of these tests is this: The parent may not deal with the subsidiary on terms more favorable than those under which an outsider would deal with the subsidiary. ${ }^{91}$ Advantages obtained by the parent in violation of this standard will be disregarded.

The simple truth is that the courts, obliged by the nature of the problem to treat each case on its merits, have been feeling their way step by step-not without resort to hindsight. Rigid rules and fixed formulas are futile in this area of hazy equities and judicial retrospections. ${ }^{92}$ Although this spells disappointment for those who crave certainty, judicial achievement in this difficult area is impressive and commendable. ${ }^{93}$

${ }^{88}$ The court, speaking of its power to disregard corporate personality and to hold the parent liable for the subsidiary's debts, said that there are various "negative rules" on the subject, and continued (p. $38 \mathrm{I}$ ): "It is impossible to formulate a general rule applicable to all cascs, and the courts have not attempted to do so. Rather the over all picture as it appears from the facts dictates whether or not the power should be exercised."

${ }^{80}$ Inadequate capitalization is an important factor in the application of the Deep Rock doctrinc. $A$ discussion of that doctrine is found in note ro4, infra.

${ }^{80}$ See Boyum v. Johnson, I27 F. 2d 49I (8th Cir. 1942), and dissent in Barlow v. Budge, 127 F. $2 \mathrm{~d}$ 440 (8th Cir. 1942). See also the next note.

Rembar, stupra, at $915 \mathrm{ff}$., suggests three tests: (I) A comparison of the subsidiary's capital with the capital of other corporations similar in size and nature. All the parent's advances which bring the subsidiary's assets up to this level are to be regarded as capital contributions. (2) The extent to which the subsidiary could have borrowed from outside sources. The parent's advances are to be regarded as capital contributions if made when the subsidiary could not have borrowed from outside sources. (3) The ratio between the parent's capital contributions and non-capital contributions. The latter must not be too great as contrasted with the former.

${ }^{01}$ Israels, The Implications and Linitations of the Deep Rock Doctrine, 42 Coc. L. Rev. 376, 391 (r942). He suggests that if there is a market for new shares, common or preferred, in the subsidiary, the parent must invest on that basis. The parent's advances made under such circumstances should be treated as capital contributions, not loans. "Perbaps only upon a showing that there was no market for common or preferred stock on reasonable terms would the parent be justified in lending moncy."

Note, Inadequately Capitalized Subsidiaries, x9 U. OF CHr. L. REv. 872, 874 (1952), speaking of the line between "legitimate debt and disguised capital," says: "One index is the extent to which continued long term borrowing from the parent occurs when the subsidiary could not have borrowed from outsiders."

${ }^{02}$ See note 88 , supra. It is to be observed, also, that hindsight is to be applied with caution and circumspection. See note 86 , supra.

${ }^{83}$ Note, Inadequately Capitalized Subsidiaries, I9 U. of CHI. L. Rev. 872, 875 (I952): "While 


\section{Legal Metaphors and Practical Realities}

The orthodox judicial analysis of the parent-subsidiary relationship differs from that advanced under the preceding heading. As is to be expected, the courts resort to words of art. Their approach is this: If the subsidiary is a mere adjunct or instrumentality of the parent, the latter will be liable for the former's contracts and torts. ${ }^{94}$ Frequent use is also made of the following words to denote synonymy to "adjunct" and "instrumentality": agency, alter ego, tool, department, conduit, double, alias, dummy, and so forth.

These words are not helpful, for they themselves need defining. Obviously, they are not incantations which produce results by the magic of utterance, but rather are verbal labels of convenience attached to results which are reached on the facts of the case. On the basis of given facts it may be felt that the parent corporation should be held liable for the contract or tort of its subsidiary. It is, of course, these facts and the decision reached which are significant. ${ }^{95}$ To say that the parent

subsequent activity indicates what was necessary in the beginning, the courts are faced with an overwhelming problem. Because quantitative criteria are often artificial and unjust, courts cannot be condemned for vaguely phrasing the variables contributing to their decisions. While incorporators have no yardstick with which to measure their transactions, they have been put on notice that the protection of their own funds is not enough, and theirs is the responsibility of creating a financial structure which will not unduly jeopardize creditors in the event of the subsidiary's insolvency."

"At Atwater \& Co. v. Fall River Pocahontas Collieries Co., 119 W. Va. 549, 559, I95 S. E. 99, I04 (1937): "The instrumentality rule is a modern innovation in the law of corporations. It came into being as a result of a gradual growth, brought about by the necessities of situations which confronted the courts. The development of the law on this question is still in progress, and therefore courts should invoke the rule only with mature consideration and caution. Undue haste in the application of the rule to every case involving corporations would break down the entire corporation law of the country and would bring about disastrous results."

For analysis and criticism of the "instrumentality rule" see May Department Stores Co. v. Union Electric Light \& Power Co., I07 S. W. 2d 4x, 53 ff. (Mo. I937); Note, 21 ST. Lours L. Rev. 234 (1936).

oc "Each case must be regarded as sui generis," it is said, and "slight shading of the facts creates possible distinctions." Pagel, Horton \& Co. v. Harmon Paper Co., 236 App. Div. 47, 49, 258 N. Y. Supp. I68, I7I (4th Dep't r932). For similar language see Herman v. Mobile Homes Corp., 3I7 Mich. $233,243,26$ N. W. $2 d 757$ (1947).

Care must be taken in noting and defining the particular issue presented by a case. Whether the parent is liable for the obligations of the subsidiary is one question. This question may itself turn on the nature of the obligation involved; conceivably, tort claimants and contract creditors might be treated differently for this purpose, though the courts have not addressed themselves to this difference. Whether the parent may share as a creditor for advances made to the subsidiary is another question. Whether the subsidiary's presence in a state is equivalent to the parent's presence there, in determining matters respecting jurisdiction and service of process, and whether the units are to be regarded as separate parties in determining the incidence of taxation under a particular statute, are still other problems. These and various other classes of issues which arise may be controlled by varying legal policies. For instance, in Centmont Corp. v. Marsch, 68 F. 2 d 460 (Ist Cir. I933), cert. denied, 291 U. S. 680 (I934), the parent was not permitted to share as a creditor for advances made to the subsidiary. But in another case, involving the same parent and subsidiary, a creditor of the subsidiary was denied recovery against the parent. Marsch v. Southern New England R. R., 230 Mass. 483, 120 N. E. 120 (Igr8). The same dichotomy appears in the following pair of cases: Re Otsego Waxed Paper Co., 14 F. Supp. I5 (S. D. Mich. 1935) (parent's claim against subsidiary subordinated to claims of subsidiary's creditors), and Madden v. Mac Sim Bar Paper Co., I03 F. 2d 974 (6th Cir. 1939) (creditor of subsidiary denied recovery against the parent).

For examples of judicial sensitivity to this matter see the statements of Justice Brandeis and Judge Learned Hand in Cannon Mfg. Co. v. Cudahy Packing Co., 267 U. S. 333, 337 (1925), and New York Trust Co. v. Island Oil \& Transport Corp., 34 F. 2d 655 (2d Cir. 1929). 
is liable in this situation because the subsidiary is a mere adjunct or instrumentality of the parent adds no substance and gives no real reason for the decision, but merely supplies verbal justification and a metaphorical tag to the conclusion which is predicated on the facts. Beneath the verbal coating dynamic forces are at play-the unexpressed factors of legal policy which constitute the real reason for decision. ${ }^{00}$ As Justice Cardozo, whose devotion to picturesque speech is well known, deftly declared: "The whole problem of the relation between parent and subsidiary corporations is one that is still involved in the mists of metaphor. Metaphors in law are to be carefully watched, for starting as devices to liberate thought, they often end by enslaving it."

Assuming that the usual judicial analysis is to be followed, the basic question remains: What circumstances will justify calling the subsidiary a mere adjunct or instrumentality of the parent? In the usual case it is a failure to honor one or more of the four standards of behavior, described above, which is the operative fact causing the subsidiary to be considered a mere adjunct of the parent. Hence, the favorite form of judicial statement, pinned down to the cases and their factual content, reduces to this: Ownership by the parent of all the subsidiary's shares, and the presence of common or identical directors and officers, are not of themselves sufficient cause to render the subsidiary an adjunct of the parent or to assimilate the units; on the other hand, a failure to honor one or more of the four standards which should characterize the activities of a parent and its subsidiary may be sufficient cause to render the subsidiary an adjunct of the parent and to assimilate the units. ${ }^{.8}$

\section{The Parent as Creditor of the Subsidiary}

A parent corporation is not permitted, upon the insolvency of a subsidiary which is a mere "adjunct," to share as creditor for sums advanced as loans to the subsidiary. $^{99}$ Conversely, the claim of the subsidiary against its insolvent parent is also

Robert S. Stevens, Private Corporations 85 (2d ed. 1949): "Whether a distinction between these personalities will be made may vary with the nature of the action in which the issue is raised, and cannot be determined in one action for all purposes."

${ }^{\circ 0}$ Taylor v. Standard Gas Co., 306 U. S. 307, 322 (r939): The "so-called instrumentality rule," said the Court, "is not, properly speaking, a rule, but a convenient way of designating the application in particular circumstances of the broader equitable principle that the doctrine of corporatc entity, recognized generally and for most purposes, will not be regarded when so to do would work fraud or injustice."

${ }^{97}$ Berkey v. Third Avenue Railway, 244 N. Y. 84, 94, I55 N. E. 58, 6I (r926). Sce also Kingston Dry Dock Co. v. Lake Champlain Transport Co., 3I F. 2d 265, 267 (2d Cir. 192r); Re Pittsburgh Railways Co., 155 F. 2d 477, 484 (3rd Cir. 1946); 22 Boston U. L. REv. I27 (1942).

${ }^{88}$ See Douglas and Shanks, Instlation From Liability Through Subsidiary Corporations, 39 YaLE L. J. I93, 195 (1929); Frederick J. Powell, Parent and Subsidiary Corporations 9 ef seq. (i93x); Note, 46 Harv. L. REv. 823 (1933).

${ }^{\circ}$ Henry v. Dolley, 99 F. 2d 94 (Ioth Cir. 1938); Re Otsego Waxed Paper Co., I4 Fed. Supp. I5 (D. Mich. x935); Central Vermont Ry v. Southern New England R. R., I Fed. Supp. roo4 (D. Mass. I932); Centmont Corp. v. Marsch, 68 F. 2 d 460 (Ist Cir. 1933); S. G. V. Co. v. S. G. V. Co., $264 \mathrm{~Pa}$. 265, 107 Atl. 72I (I919); Clere Clothing Co. v. Union Trust \& Savings Bank, 224 Fed. 363 (gth Cir. I915).

"The reason is that the proprietor of a business cannot lend money to the enterprise and thus curtail the rights of creditors by sharing in pari passu with them, and such loan is regarded as a contribution to the capital of the business." New York Trust Co. v. Island Oil \& Transport Co., 56 F. 2d 580, 583 
rejected. ${ }^{100}$

These are sound results based on the desire to protect the creditors of the two units. In the first situation the insolvent subsidiary's creditors are protected against further depletion of the assets available for the payment of their claims; in the second situation, the insolvent parent's creditors are protected against further depletion of the assets available for the payment of their claims.

In the cases which reject ${ }^{101}$ the parent corporation's claim against the insolvent subsidiary there are present facts-such as "intermingling," failure to observe the formalities of separate corporate action, inadequate financing of the subsidiary as a separate unit-which justify calling the subsidiary a mere adjunct of the parent. Whether the same result would follow in the absence of such facts is open to question. The desire to protect the subsidiary's creditors may, conceivably, be in itself sufficient ground to induce a court to treat the subsidiary as a mere adjunct of the parent and to reject the parent's claim. ${ }^{102}$ In the case of the one-man company it is held, as already seen, that the sole shareholder who keeps his individual affairs distinct from the corporate venture may lend money to the business and share as a creditor upon its insolvency. There appears to be no logical or practical reason why the corporate shareholder in the parent-subsidiary pattern should be treated differently in this respect from the human shareholder in the one-man company. Therefore, a parent corporation which has honored the four standards that should characterize the activities of parent and subsidiary units may, it is believed, share as a creditor for its loans to the subsidiary, upon the latter's insolvency. The available cases on the point are to this effect. ${ }^{103}$

Cases in which the parent seeks to share as a creditor for its advances to the subsidiary frequently raise two particular problems.

(2d Cir. 1932).

Allowance of the parent's claim would be "tantamount to allowing a debtor to prove in bankruptcy in competition with its own creditors, a result which shocks the conscience of a chancellor." Central Vermont Ry. v. Southern New England R. R:, cited above, stupra at 1005.

${ }^{100} \mathrm{New}$ York Trust Co. v. Island Oil \& Transport Co., 34 F. 2d 655 (2d Cir. 1929).

${ }^{101}$ If the parent's claim against the insolvent subsidiary is subordinated to the claims of the subsidiary's other creditors, the latter will exhaust the subsidiary's assets and leave nothing for the parent, in the usual case. Hence, in these situations subordinating the parent's claim is, for all practical purposes, equivalent to disallowing it. See Note, 47 Cot. L. Rev. 800,804 n. 38 (I947).

Furthermore, when courts wish to disregard corporate personality and to assimilate the units, they do so on the premise that the subsidiary is a mere adjunct or instrumentality of the parent. Under this approach the parent cannot be considered a creditor of the subsidiary, since a party cannot assert a claim as creditor against himself. Accordingly it would be more appropriate to speak of disallowing the claim, rather than of subordinating it, in these cases.

In view of these considerations it is not surprising to find that almost all the cases dealing with these matters speak of disallowance or rejection, rather than of subordination.

See Note, Stubordination of a Parent's Clainz Against a Stubsidiary, 36 ILr. L. Rev. 229, 230, 232 (1941).

${ }^{102}$ See Note, 46 HaRv. L. Rev. 823,828 (1933).

${ }^{103}$ Sce Re Watertown Paper Co., 169 Fed. 252 (2d Cir. 1909); Finn v. George T. Mickle Lumber Co., 4I F. 2d 676 (9th Cir. x930); Franklin Process Co. v. Western Franklin Process Co., 308 Ill. App. 302, 3 I N. E. $2 d{ }^{2} 64$ (194I); Note, 37 MrCH. L. Rev. 440 (1939); Note, 45 YaIE L. J. I 47 I (1936). Cf. Forbush Co. v. Bartley, 78 F. 2d 805 (roth Cir. 1935) (parent's claim denied because based on fraudulent and forged entries). 
The first is the problem of adequate capitalization of the subsidiary. Here the question arises whether the advances made to the subsidiary are to be regarded as genuine loans, for which the parent may share as a creditor of the subsidiary, or merely as contributions to the subsidiary's capital, for which the parent's claim must be subordinated to the claims of the subsidiary's creditors. This matter was touched upon above when the question of adequate capitalization of the subsidiary was under discussion.

The second problem concerns the legal incidents which ensue when insolvency has overtaken both the parent and its "adjunct" subsidiary. Here, if the parent's claim is denied, or is subordinated to the claims of the subsidiary's creditors, the latter will benefit at the expense of the parent's creditors. If the parent's claim is allowed, without subordination, its creditors will benefit at the expense of the subsidiary's creditors. The contest is, therefore, really one between the respective creditors of each unit. This problem is considered under the next heading.

\section{E. Competing Equities of Each Unit's Creditors ${ }^{104}$}

A difficult problem which arises when the parent corporation and its "adjunct" subsidiary are assimilated concerns the general or unsecured creditors of the two

104 The Supreme Court's decision in the famous Deep Rock case has become, and scems destincd to remain, the cynosure in this matter of the equities of rival claimants in the intercorporate community. Taylor v. Standard Gas Co., 306 U. S. 307 (1939). Here it was found that the subsidiary was undercapitalized and was the victim of mismanagement and spoliation by the parcnt, and that the affairs of the two units had been commingled. The parent held an enormous claim for advances to the subsidiary. In corporate reorganization procedings under the Bankruptcy Act a plan of reorganization was filcd under which the parent's claim was compromised and the subsidiary's nonvoting preferred shareholders reccived very little. The plan was held to be unfair and judicial confirmation was denied. The parent's claim, it was decided, must be subordinated to the equity of the subsidiary's preferred shareholders. The decision vindicates the prophecy made in Note, Priority Between Parent Corporation and Preferred Stockholders of Its Bankrtipt Stıbsidiary, 36 Mici. L. Rev. 88 (1937).

Two years later the court rendered another decision to the same effect. Consolidated Rock Co. v. Du Bois, 312 U. S. 510 (I94I). Here the court found that the subsidiary had "abdicated" and that the parent had "directly" managed the subsidiary as a "mere department." A plan of corporate reorganization under which the parent's assets were insulated from the claims of the subsidiary's bondholders was, accordingly, held to be unfair, and judicial confirmation was denied. Accord: Re Commonwcalth Light \& Power Co., r4I F. 2d 734 (7th Cir. r944) (stressing inadequate capitalization of the subsidiary).

In 1948 the Court was asked once again to invoke the Deep Rock doctrine, but refused to do so. Comstock v. Group of Institutional Investors, 335 U. S. 21 I (1948). The justices observed that the Deep Rock case was based on the particular equities there presented. A majority of them felt that the instant case lacked the equities present in the earlier cases. Four of the justices thought otherwise and dissented vigorously.

Much ink has been spilled over this subject. See Israels, The Implications and Limitations of the Deep Rock Doctrine, 42 Col. L. Rev. 376 (1942); Krotinger, The Deep Rock Doctrine: A Realistic Approach to Parent-Subsidiary Latv, 42 CoL. L. Rev. I124 (x942); Sprecher, The Conflict of Equities Under the Deep Rock Doctrine, 43 Col. L. Rev. 336 (1943); Bayne, The Deep Rock Doctrine Reconsidered, x9 Fordham L. Rev. 43, 152 (1950); Note, The Deep Rock Doctrine: Inexorable Command or Equitable Remedy?, 47 Cor. L. REv. 800 (r947); Note, Limiting the Deep Rock Doctrine, 58 Yaln L. J. 773 (I949); Note, Deep Rock Duz Everything, 29 TEx L. REv. 71 (1950).

The Deep Rock doctrine has been well received and has been much praised. For cxample, sce Krotinger, supra, at II46: "The Deep Rock case has the potentiality of setting the law of parent-subsidiary claims on a realistic plane. Even from the meagre line of rulings made since the Supreme Court handed down that decision, it is apparent that the claims of the dominant stockholder in a subsidiary or "one-man" corporation will be more closely scrutinized with a view to setting equitable limitations on 
units. Three facets of the problem are revealed. The first is the situation in which the parent corporation is insolvent and the subsidiary is solvent. The second is the situation in which the parent corporation is solvent and the subsidiary is insolvent. The third is the situation in which both the parent and the subsidiary are insolvent.

In the first case (insolvent parent, solvent subsidiary), the assets of the subsidiary are regarded as assets of the parent for purposes of administration. ${ }^{105}$ The parent's receiver or trustee in bankruptcy is entitled to take charge of and administer the subsidiary's assets, ${ }^{106}$ and creditors of the parent may have a receiver appointed for the subsidiary. ${ }^{107}$ The basic qualification is, however, that the rights of the subsidiary's creditors may not be impaired. They are entitled to priority in the subsidiary's assets. Those assets are treated as a separate fund for the benefit of the subsidiary's creditors, and the balance left after satisfying them goes to the parent for the satisfaction of its creditors. ${ }^{108}$

Conversely, in the second case (solvent parent, insolvent subsidiary), the subsidiary's creditors should not be permitted to jeopardize the rights of the parent's creditors. ${ }^{100}$

In the third case (parent and subsidiary both insolvent), the struggle of con-

the use of the debtor-creditor relationship. It is the writer's belief that we shall see a more discriminating approach to questions of subordination, with a view to a more accurate shaping of the remedy to meet the needs of the individual case." See also Note, 54 Harv. L. Rev. 1045, 105I (I94I).

A dissenting voice in the chorus of praise is Bayne, stupra, at $18 \mathrm{I}$, who concludes his elaborate analysis with the comment that "the most prudent and guarded course would be, it is submitted, abandonment of the holding as a doctrine capable of accurate and intelligent application to facts and circumstances in litigation."

${ }^{105}$ Re Eilers Music House, 270 Fed. 915 ( 9 th Cir. I92I) (there was apparently "intermingling" of intercorporate affairs here); Day v. Postal Telegraph Co., 66 Md. 354, 7 Atl. 608 (1887) (subsidiary undercapitalized, no separate accounts kept, parent by direct intervention managed property of subsidiary without consulting latter's directors). See Re Muncie Pulp Co., 139 Fed. 546 (2d Cir. I905).

${ }^{200}$ Commerce Trust Co. v. Woodbury, 77 F. $2 \mathrm{~d} 478$ (8th Cir. 1935) (subsidiary sales company considered an adjunct or department of the parent because the latter's president "had the power to remove any officer or director of the sales company without consideration or notice, and to dominate and control performance of its contracts"); Central Republic Bank \& Trust Co. v. Caldwell, 58 F. 2d 72x, 735 (8th $\mathrm{Cir}$. 1932): "We think the relationship existing between the two corporations was of such character and the intermingling of assets so extensive that the trial court was right in directing the bankrupt's receiver to take charge of the whole assets pending further action by the court, and that justice to all parties interested will best be done by such procedure."

${ }^{107}$ Trustees System Co. of Pennsylvania v. Payne, 65 F. 2d I03 (3d Cir. I933). Here creditors of the insolvent parent, which was in the hands of a receiver, requested the court to appoint receivers for a string of solvent subsidiaries. The court (p. 107) granted the request on the ground that the parent and its subsidiaries "were not merely related by stock ownership but, like wheels in a machine, were so closely meshed that all functioned together" and were "really one company."

${ }^{108}$ Commerce Trust Co. v. Woodbury, 77 F. 2d 478 (8th Cir. 1935). See Simon v. Chambless, 86 F. 2d 569 (5th Cir. 1936). Cf. Re Clark Supply Co., Inc., and Re Todd Bldg. Corp., r72 F. 2d 248, 254 (7th Cir. 1949).

"Hence, where an instrumentality relationship has been found, the courts have disregarded the subsidiary's corporate entity and allowed the receiver [of the parent] to assume direct control over the assets held by the affiliate as property of the parent." However, "the subsidiary's creditors will be completely protected by according them priority in the assets taken over," whereas "the parent's creditors may benefit from the increment in value resulting from an at least temporary preservation of the system." Note, 46 HARv. L. Rev. 823, 827 (1933).

${ }_{100}$ Note, 46 Harv. L. REv. 823, 825 (1933). See Rembar, Claims Against Affliated Companies in Reorganization, 39 CoL. L. REv. 907, 912 (1939). 
flicting equities reaches its climax. The available authority yields no definitive answer on this specific issue. ${ }^{110}$ One possible solution, which might lead to quixotic results if indiscriminately applied, is to lump together the assets of both units and permit the creditors of both units to share this common fund pro rata. ${ }^{111}$ Another solution, which would better accord with prevailing concepts in other legal areas, is to assemble the respective assets of the parent and subsidiary into two separate funds and give each set of creditors priority in its particular fund. The parent's creditors receive priority in the parent's assets, and the subsidiary's creditors receive priority in the subsidiary's assets. ${ }^{112}$ In the analogous situation when a partnership and the partners are all insolvent, the majority common law rule, the Uniform Partnership Act, and the Bankrupcy Act adopt a similar arrangement whereby the assets are marshaled as follows: The partnership creditors enjoy priority in the partnership assets, and the individual creditors of each partner enjoy priority in that partner's personal assets. ${ }^{113}$

The foregoing principles serve merely as general guides. Their chief virtues are their relative certainty, ease of application, and comparative fairness. It is not humanly possible, of course, to frame a set of rules which can be uniformly applied

${ }^{110}$ See Note, 46 Harv. L. Rev. 823, 825 n.13 (1933). Cf. Re Fox West Coast Theatres, 88 F. 2 d 212 (9th Cir. 1937). In Henry v. Dolley, 99 F. 2d 94 (10th Cir. 1938), this question was raised by counsel, but the court avoided deciding the issue. In this case the insolvent parent's claim against its insolvent "adjunct" subsidiary was subordinated to the claims of the subsidiary's other creditors. The court said (p. 97): "Counsel for the Telephone Company further assert that it would be incquitable to the creditors of the Telephone Company to subordinate its claim to the claims of other general creditors of the bankrupt. No creditor of the Telephone Company has intervened in the proceeding and there is no showing that the subordination of the Telephone Company's claim would prejudice its creditors. The trustees of the Telephone Company have not asserted that the assets of that company and the bankrupt should be consolidated and the several creditors of the two companies placed on a parity, and that relief has not been sought either by the trustees or by any creditor of the Telephone Company. This being true, we are of the opinion that the claim must be disposed of on a consideration of the rights of the Telephone Company and the creditors of the bankrupt."

${ }^{111}$ Elvin R. LatTy, Subsidiaries and Affiliated Corporations 154 (x936): "Perhaps the fairest way of dealing with the situation when both the parent and subsidiary corporations are insolvent is to let all the creditors of each share pro rata in the pooled assets of both. Such procedure would be especially equitable where the claimants are creditors of both the parent and the subsidiary."

${ }_{112}$ A good discussion is found in Note, The Deep Rock Doctrine: Inexorable Command or Equitable Remedy?, 47 CoL. L. REv. 800, 8I If. (1947). The writer presents three possible solutions in cases where both units are insolvent and the parent is pressing a claim as creditor for advances to the subsidiary: (I) let the parent share as creditor for the benefit of its creditors; (2) subordinate the parent's claim for the benefit of the subsidiary's creditors; (3) pool the assets of both units and permit all the creditors to share pro rata in the common fund. He then says: "It is possible, and indeed may be necessary, to combine (3) with either (1) or (2) in order to achieve a just solution."

Note, Parent Corporation's Claim in Bankruptcy of Subsidiary, 54 Harv. L. Rev. 1045, 1050 (1941): "This problem is particularly acute when the parent is also insolvent; the conflict is then between two sets of creditors, both of which may include public investors. Although the cases have attached little significance to the insolvency of the parent, it might be argued that in such a situation advances up to what would be an adequate capital should be treated, in effect, as capital contributions, and that thereafter claims for which the subsidiary received and retained a fair consideration should be given the status of debts."

${ }^{113}$ Farmers' \& Mechanics' National Bank v. Ridge Avenue Bank, 240 U. S. 498 (1916); Rodgers v. Meranda, 7 Ohio I80 (1857); UnIForm PartNership Act $\$ 40(\mathrm{~h})$ (i), 7 U. L. A. $\$ 40$ (h) (i) (Ig22). Contra: Robinson v. Security Co., 87 Conn. 268, 87 Atl. 879 (I9I3), which applies the "minority common law rule." 
with complete fairness to every situation which may arise. This area is, manifestly, one of delicate shadings and refined equities. The elemental wisdom of deciding within the factual framework and individual merits of each case applies with full force. The particular circumstances of a case may well justify or require a departure from a prescribed general scheme of marshaling.

A court, vexed with the difficulty of these problems, may be quick to seize upon a particular circumstance as an equity which favors one group of creditors at the expense of the others. For example, in one case the court allowed the insolvent parent's creditors to share in the insolvent subsidiary's assets together with the subsidiary's creditors, because the latter became creditors with knowledge that the subsidiary was a mere adjunct of the parent. ${ }^{114}$ Likewise, another court indicates that under certain circumstances the insolvent subsidiary's creditors may exhaust its assets and then share for the balance of their claims in the insolvent parent's assets together with the parent's creditors. ${ }^{115}$ In still another case it appeared that if the assets of parent and subsidiary were segregated, and each unit's creditors were given priority in their respective funds, a grossly unfair distribution would result. ${ }^{116}$ Accordingly, the court, in order to permit a more equitable distribution, consolidated the bankruptcy proceedings against the parent and the subsidiary and pooled the assets of both units for pro rata sharing by all the creditors. ${ }^{117}$

11' New York Trust Co. v. Island Oil \& Transport Co., 56 F. 2d 580 (2d Cir. I932).

${ }^{115}$ See Commerce Trust Co. v. Woodbury, 77 F. 2d 478, 49I (8th Cir. 1935).

${ }^{110}$ Stone v. Eacho, I27 F. 2d 284, 288 (4th Cir. 1942), cert. denied, 3I7 U. S. 635 (I942): "If the Virginia corporation is treated as a separate entity and the property used in the Richmond business is applied to its debts, and the claim of the Delaware corporation is postponed, in accordance with the ruling below, those creditors who have dealt with the Richmond store and have proven claims in the Virginia proceeding, will have their claims practically paid in full, whereas other creditors of the Delaware corporation will receive less than $30 \%$ on their claims in the bankruptcy proceeding pending in New Jersey. If on the other hand, the Virginia corporation is treated as a separate entity and the claim of the Delaware corporation is not postponed, this claim will so far absorb the assets at Richmond that other creditors proving in the Virginia proceeding will receive less than half the dividend received by creditors in the New Jersey proceeding. Only by entirely ignoring the separate corporate entity of the Virginia corporation and consolidating the proceedings here with those of the parent corporation in New Jersey can all the creditors receive that equality of treatment which it is the purpose of the bankruptcy act to afford; and this, we think, is the course that should be followed."

${ }^{117}$ Stone v. Eacho, supra. The court said (p. 288): "It is too well settled to admit of argument that the claims of a parent corporation against a subsidiary should be thus postponed where the subsidiary, as here, has in reality no separate existence, is not adequately capitalized, and constitutes a mere instrumentality of the parent corporation or a mere 'corporate pocket' or department of its business. . . . And even in the case of the insolvency of both corporations there may be reason for recognizing the separate entity of the subsidiary and postponing the claim of the parent, where the subsidiary has been allowed to transact business as an independent corporation and credit has been extended to it as such on the faith of its ownership of the assets in its possession. LATTY, Subsidiaries AND AfFiliated Corporations 153-155. But in a case such as this, where both corporations are insolvent, where the business has been transacted by and the credit extended to the parent corporation, and where the subsidiary has no real existence whatever, there is no reason why the courts should not face the realities of the situation and ignore the subsidiary for all purposes, allowing the creditors of both corporations to share equally in the pooled assets." See Sprecher, The Confict of Equities Under the Deep Rock Doctrine, 43 Cor. L. Rev. 336, 352 (1943); Krotinger, The Deep Rock Doctrine: A Realistic Approach to Parent-Subsidiary Law, 42 CoL. L. REv. $1124,1 \times 42 f$. (1942); Israels, The Implications and Limitations of the Deep Rock Doctrine, 42 CoL. L. REv. 376, 388, 389, 393 (I942); Rembar, Claims Against Affiliated Companies in Reorganization, 39 CoL. L. Rev. 907, 919 f. (x939). 
Future action in this arena of legal controversy will, therefore, depend more upon judicial sensitivity to the equities of a case than upon the verbal sweep of general rules. ${ }^{118}$

A similar situation and a decision to the same effect will be found in $R e$ Associated Gas \& Elec. Co., I49 F. 2d 996 (2d Cir. 1945), cert. denied, 326 U. S. 736 (r945), where the court was moved by the desire to protect the subsidiary's, rather than the parent's, creditors.

118 "Equity looks in all directions. Only in that way can the various interests in the corporate community be adequately protected." Justice Murphy, dissenting, in Comstock v. Group of Institutional Investors, 335 U. S. $2 \times 1,238$ (x948). 